\title{
Targeted PET/MRI Imaging Super Probes: A Critical Review of Opportunities and Challenges
}

\author{
Anna Kastelik- \\ Hryniewiecka ${ }^{1,2}$ \\ Pawel Jewula ${ }^{3}$ \\ Karolina Bakalorz' \\ Gabriela Kramer-Marek ${ }^{2,4}$ \\ Nikodem Kuźnik (iD) \\ 'Silesian University of Technology, Faculty \\ of Chemistry, Gliwice, Poland; \\ ${ }^{2}$ Radiopharmacy and Preclinical PET \\ Imaging Unit, Maria Sklodowska-Curie \\ National Research Institute of Oncology, \\ Gliwice, Poland; ${ }^{3}$ Central European \\ Institute of Technology, Brno University \\ of Technology, Brno, Czech Republic; \\ ${ }^{4}$ Division of Radiotherapy and Imaging, \\ The Institute of Cancer Research, \\ London, UK
}

\begin{abstract}
Recently, the demand for hybrid PET/MRI imaging techniques has increased significantly, which has sparked the investigation into new ways to simultaneously track multiple molecular targets and improve the localization and expression of biochemical markers. Multimodal imaging probes have recently emerged as powerful tools for improving the detection sensitivity and accuracy - both important factors in disease diagnosis and treatment; however, only a limited number of bimodal probes have been investigated in preclinical models. Herein, we briefly describe the strengths and limitations of PET and MRI modalities and highlight the need for the development of multimodal molecularly-targeted agents. We have tried to thoroughly summarize data on bimodal probes available on PubMed. Emphasis was placed on their design, safety profiles, pharmacokinetics, and clearance properties. The challenges in PET/MR probe development using a number of illustrative examples are also discussed, along with future research directions for these novel conjugates.
\end{abstract}

Keywords: medical imaging, bioresponsive probes, targeting, contrast agents, relaxivity, clearance

\section{Introduction}

Efforts to improve the earlier diagnosis of cancer are multifaceted. Standard laboratory tests are beneficial due to their accessibility, relatively low costs, and specificity, but their routine use requires clear guidelines. ${ }^{1}$ With the shift to noninvasive disease diagnosis and novel treatment regimens, molecular imaging has gathered remarkable momentum in practical applications over the past few decades and has played a profound role in monitoring disease progression and facilitating drug research. Imaging modalities allow for the non-invasive, real-time visualization and quantification of physiological and pathological processes at the cellular and molecular levels, allowing for the better management of cancer treatment.

Currently, molecular imaging uses mainstream technologies such as X-ray computed tomography (CT), magnetic resonance imaging (MRI), positron emission tomography (PET), and single-photon emission computed tomography (SPECT), as well as optical and ultrasound (US) imaging. These techniques require highlysensitive instruments and specific imaging probes that link the imaging signal with a molecular event. Each of these modalities has pros and cons. For example, CT is widely available, has a fast acquisition time and high spatial resolution, but
Correspondence: Nikodem Kuźnik;

Gabriela Kramer-Marek

Tel +48 $694220077 ;+442087224412$

Fax +4832237 I3 08; +44207370526I

Email nikodem.kuznik@polsl.pl;

Gabriela.Kramer-Marek@icr.ac.uk 
due to its poor sensitivity $\left(10^{-2}-10^{-3} \mathrm{~mol} / \mathrm{L}\right)$, it is sometimes combined with SPECT or PET to capture biochemical and physiological processes. ${ }^{2}$ Moreover, CT is associated with high radiation exposure and provides relatively low-contrast images of soft tissues. MRI does not use ionizing radiation, ${ }^{3}$ has a high spatial resolution $(\sim 100$ $\mu \mathrm{m}),{ }^{4}$ and delivers information about soft tissues, but it also has a low sensitivity. In contrast, PET has an extremely high sensitivity $\left(10^{-11}-10^{-12} \mathrm{~mol} / \mathrm{L}\right)$, limitless depth of penetration, and quantitative capabilities, but it lacks anatomical parameters to identify molecular events. ${ }^{5}$ Tremendous improvements have recently been made in the development of imaging modalities (eg, PET/MRI systems) and image reconstruction algorithms, and also in the design of novel imaging agents. Among these are probes that can directly recognize and bind to the targets of interest, as well as probes that are conjugated in a multivalent fashion to the surface of nanoparticles. Some probes may leverage natural processes for uptake or retention, and some be activated by disease-related processes. Our experience in the design and characterization of MRI and PET contrast agents has prompted us to critically review some of the benefits and possible pitfalls of the recently reported bimodal probes.

Herein, we discuss how we can use physicochemical properties to predict major in vivo effects such as the clearance route and undesired deposition in various systems and how to assess the dose required to achieve signal enhancement in the region of interest.

\section{Imaging Techniques Specificity of MRI and PET}

MRI is a tomography technique based on nuclear magnetic resonance (NMR). In some atoms (such as ${ }^{1} \mathrm{H},{ }^{13} \mathrm{C},{ }^{31} \mathrm{P}$, or

${ }^{19} \mathrm{~F}$ ), nuclides (often miscalled as isotopes) ${ }^{6}$ adopt different energy states in a high magnetic field. In medical practice, the field strength ranges from 1.5 to $3.0 \mathrm{~T}\left(B_{0}\right)$, which is a hundred thousand times stronger than that of the Earth. After the radiofrequency (RF) pulse is applied to excite the nuclei, the nuclear magnetic spins rapidly return to their original equilibrium energy levels in a process called relaxation (Figure 1). There are two types of relaxationlongitudinal and transverse-which are expressed by the time constants, $T_{1}$ and $T_{2}$, respectively. Additionally, the intrinsic imperfections of the magnetic field lead to relaxation faster than $T_{2}$ recorded as $T_{2}{ }^{*}{ }^{7}$ Fortunately, many biogenic substances contain MRI-active nuclides, where

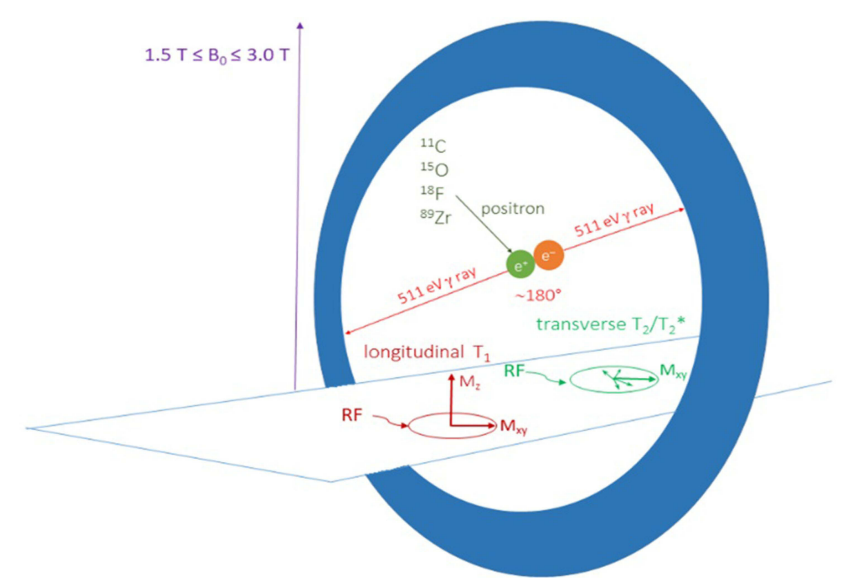

Figure I Graphical representation of the principle of the MRI and PET techniques.

${ }^{1} \mathrm{H}$ is the most common; therefore, MRI scanners are tuned to ${ }^{1} \mathrm{H}$ in water, which makes up $73 \%$ of the fat-free mass of human bodies, but also in fat, proteins, and sugars.

The outlines of tissues, organs, and all abnormalities are revealed in the images due to the specific mobility of ${ }^{1} \mathrm{H}$ present in these organic molecules. MRI is a superior imaging modality for visualizing soft tissues like the gastric tract, cardiovascular system, and, most commonly, the brain and central nervous system. ${ }^{8}$ Some MRI sequences can differentiate between water and fat, which is useful for the evaluation of adrenal tumors. Similar fat-suppression sequences (eg, CHESS, fat-sat) are used to enhance the contrast resolution and improve the visibility of lesions to determine their lipid contents and remove artifacts. Furthermore, MRI's good temporal resolution allows the monitoring of dynamic changes, eg, angiography and functional MRI (fMRI), which can be used to track blood flow and brain activity as a function of signal change vs time.

In PET imaging, the detected signal originates from the radioactive decay of neutron-deficient radionuclides (eg, ${ }^{11} \mathrm{C},{ }^{15} \mathrm{O},{ }^{18} \mathrm{~F}$, and ${ }^{89} \mathrm{Zr}$ ). These specific atoms emit positrons from unstable nuclei. When traveling, the particles rapidly lose their kinetic energy by spreading around the tissue before finally being annihilated by a nearby electron. This process leads to the emission of two $511 \mathrm{keV}$ photons emitted in almost opposite directions $\left(180^{\circ}\right.$ apart, ${ }^{9}$ (Figure 1)). Subsequently, scintillation detectors surrounding the patient convert the electrical signal into sinograms that are subsequently rebuilt into tomographic images. ${ }^{5}$ The radiotracers (in this work interchangeably referred to as radioligands, radiopharmaceuticals, and for unification with MRI - contrast agents) used in PET consist of 
a radioactive tag bound to an organic ligand (a targeting agent). The ligand of each radiotracer interacts with a target molecule, resulting in a characteristic distribution of the radiotracer throughout the body. From a chemical point of view, radioligands are identical to their nonradioactive equivalents, so they show the same in vivo behavior. In contrast to conventional modalities (eg, US, CT, MRI) PET provides a functional or metabolic assessment of normal tissues or pathological conditions because biochemical changes usually occur before anatomical and structural changes become evident in MRI or CT. ${ }^{10,11}$

In the last 20 years, the idea of combining both MRI and PET into a single device that can simultaneously acquire both datasets has raised interest. The potential benefits of PET/MRI compared with PET/CT include an improved detection rate in selected cancers and an overall reduced radiation exposure, which may be particularly beneficial for pediatric patients. In line with this, several groups have focused on the development and characterization of PET/MRI bimodal contrast agents. ${ }^{12-14}$

\section{Probe Characteristics MRI Probes}

The diagnostic value of MRI is enhanced by the possibility of changing signals using contrast agents (CAs). At least $1 / 3$ of all examinations using MRI in the US and Europe are performed by administering magnetically-active substances, which shortens the relaxation times. CAs such as paramagnetic ion complexes or superparamagnetic particles contain lanthanide elements such as gadolinium $\left(\mathrm{Gd}^{3+}\right)$ or the transition metal manganese $\left(\mathrm{Mn}^{2+}\right)$. Most paramagnetic contrast agents are positive agents that shorten the $T_{1}$ relaxation time, leading to increased signal intensity in $T_{1}$-weighted images (the enhanced region appears brighter). On the contrary, superparamagnetic agents are negative CAs, which reduce the signal intensity in $T_{2}$-weighted images (the enhanced region appears darker).

Positive CAs are used to evaluate lesions and tumors because they increase the signal intensity in vessels and tissues, especially where there are perfusions or disruptions. Negative CAs highlight, eg, damages in capillary membranes and gastrointestinal bleedings; ${ }^{15}$ however, in this case, the strong magnetization often causes undesired signal disappearance and blurring, known as susceptibility artifacts; therefore, positive contrast agents are generally favored. ${ }^{16,17}$
MRI CAs affect the local magnetic field of water protons, leading to a specific acceleration in their relaxation, known as proton relaxation enhancement (PRE); ${ }^{18}$ therefore, magnetic species are not directly recorded by the MRI scanner, but rather their consequent interactions with water molecules. Accordingly, understanding the relaxation mechanisms and specific influence of the magnetic species on water is crucial for designing and developing CAs. The relaxation mechanism of water protons accelerated by small-molecule paramagnetic complexes, which constitute the majority of the positive CAs, has been precisely described. ${ }^{19-21}$ Two factors are directly related to the interaction of water molecules with CAs: the number of water molecules coordinated to the paramagnetic center $q$, and the rate of water exchange by the center, expressed as the residence lifetime of coordinated water $T_{\mathrm{M}}$. Two other specific features of the probe contribute to the relaxation mechanism, ie, tumbling, expressed as rotational correlation time $T_{\mathrm{R}}$, and the relaxation of the paramagnet's electrons, $T_{1 e}$ (Figure 2).

Indirect, weaker, more distant interactions have been identified and exploited during the design of CAs, but major efforts have been expended to control the tumbling of paramagnetic species. One of the most spectacular effects has been observed for interactions with protein molecules such as albumin. Tumbling can be limited by anchoring the

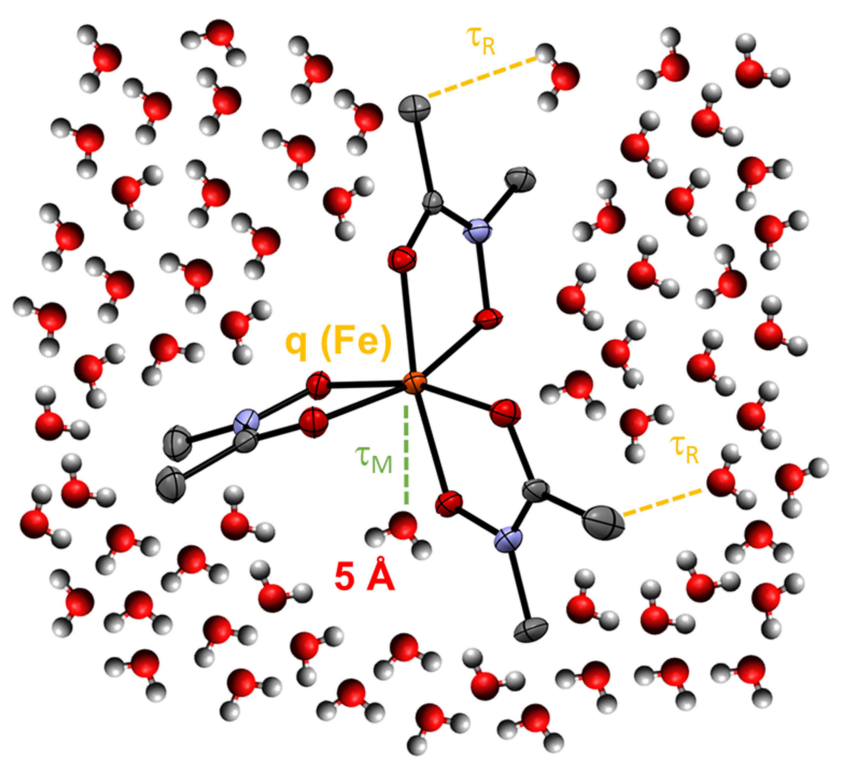

Figure 2 Solvent molecules $\left(\mathrm{H}_{2} \mathrm{O}\right)$ and the $\mathrm{Fe}(\mathrm{III})$ and $\mathrm{N}$-methylacetohydroxamate $\left(\mathrm{NMA}^{-}\right.$) complex, as well as the specific chemical interactions. The ORTEP view [source: Mercury program 3.10.1 (Build 168220).] of the [Fe(NMA) ${ }_{3}$ ] crystal structure $^{22}$ was generated using atomic coordinates taken from the CSD database (structure code: CCDC 1538337). 
probe onto a large protein globule, leading to a much more efficient acceleration in the water relaxation. This effect greatly brightens the MRI images due to the interactions with macromolecules and is known as receptor-induced magnetization enhancement (RIME, (Figure 3)). Interestingly, the results of interactions are not yet mathematically described and have rather experimental nature. This is the major reason why the observed in vivo effects are not precisely designable yet; ${ }^{7}$ however, this review, supported by large amounts of experimental data from the literature, aims to identify the main relationship between the chemical or physical factors of CAs and their visual effects in the imaging techniques.

Nanoparticles (NPs), which belong to the negative CAs group, fall into a completely different field of relaxation theory, whose description is much more general, yet suffers from the identification of precise factors. Thus, the features contributing to their relaxation mechanism mainly include the following physical properties: size (often presented as a distribution), shape (mostly globular), and magnetic moment (in the range of superparamagnets). Although size is one of the most important parameters, its determination is often ambiguous. TEM images can visualize single-particles, while the hydrodynamic radius (reaching up to $140 \mathrm{~nm})^{23}$ can be used to reveal agglomeration in dispersions. Surface functionalization reduces the description of the mechanism back to the molecular level; therefore, NPs have also been well-studied for molecular imaging applications (Figure 4). ${ }^{15}$ An interesting discussion of the complexity of the relaxation mechanism for gadolinium complexes anchored on NPs has been presented by Verwilst. ${ }^{24}$ This is an essential approach for understanding the impact of both NPs, as the massive component-which are not limited to the function of a support - and the small molecules introduced on the surface of NPs.
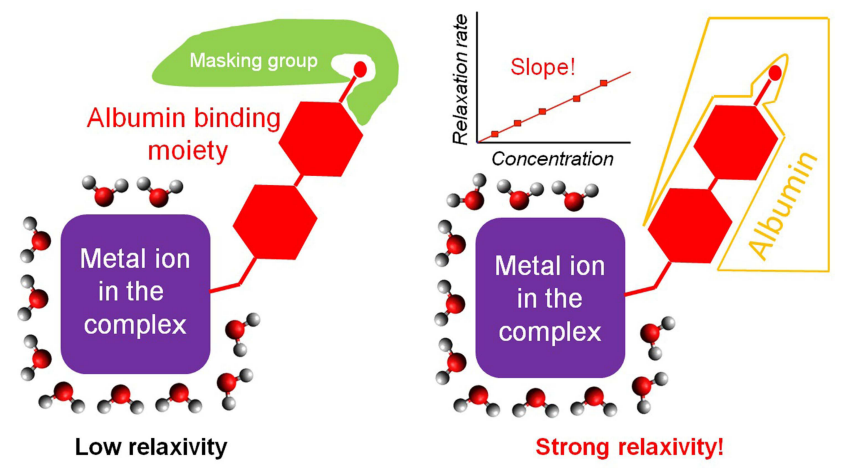

Figure 3 RIME (receptor-induced magnetization enhancement) effect.

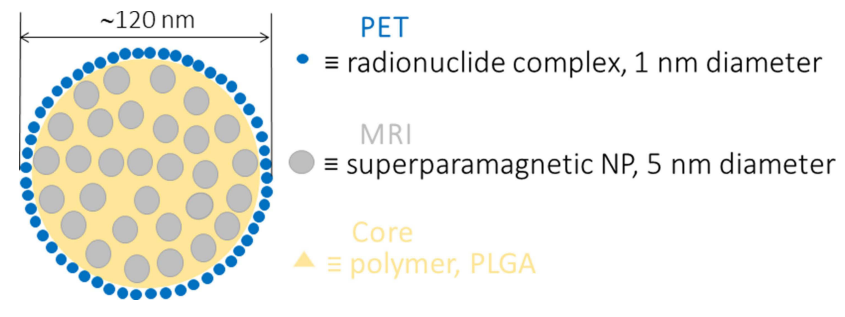

Figure 4 Ideological presentation of an MRI/PET probe based on chelated radionuclides (metal complex for PET imaging) and superparamagnetic iron oxides (SPION for MRI contrast).

The magnetic properties of the probes encompass different factors, which are particularly complex in NPs. In practice, magnetic species accelerate both $T_{1}$ and $T_{2}$ relaxation times. If the $T_{1}$ effects are dominant or at least not overwhelmed by $T_{2}$ acceleration, then such a probe is a promising positive contrast agent. Such an assessment might be done using the $r_{2} / r_{1}$ ratio. $^{25}$ When it falls into the range of $1-2$, brightened images are observed and are not distorted by $T_{2}$ effects; however, a good negative contrast agent should express a ratio of at least 20. Due to the assumption of the universality of the contrast agents with respect to the strength of the magnetic field $\left(B_{0}\right)$ and the predictability of the influence of $B_{0}$ on $r_{1}$ and $r_{2}$, NMRD (nuclear magnetic relaxation dispersion) experimental studies have been performed. ${ }^{26}$ Designing new probes with an appropriate $r_{2} / r_{1}$ ratio should be one of the criteria, which should be validated using experimental data. In radiological practice, susceptibility to artifacts causes a high deviation in this range, particularly for positive contrast agents (Table 1). In a large series of MRI candidates, there are examples of such a well-thought-out design. Kellar proposed iron oxide NPs with an oxidized starch coating as a $T_{1}$ CA with $r_{2} / r_{1}=1.69\left(0.47 \mathrm{~T}, 35{ }^{\circ} \mathrm{C}\right) .{ }^{27}$ Another relaxometric measurement of $\mathrm{Fe}_{2} \mathrm{O}_{3}$ in an aqueous dispersion did not exceed an $r_{2} / r_{1}$ ratio of 2 in a low magnetic field, ${ }^{28}$ but most low-diameter iron oxides have high $r_{2} / r_{1}$ ratios. ${ }^{29}$ An interesting approach was published by Gazeu, where gadolinium was chelated on carbon nanotubes, where the resulting $r_{2} / r_{1}$ ratio was close to 1 and almost field-insensitive. ${ }^{30}$ Carbon nanotubes are known for their strong effect on $T_{2}{ }^{31}$

Another factor compared in MRI contrast agent studies is the relaxivity (Table 1). This value is relatively easy to determine in vitro. It is assumed that high relaxivity values will directly cause an explicit, clear image in the region of interest. Most often, it is expressed in units of $\mathrm{mM}^{-1} \mathrm{~s}^{-1}$, which initially came from gadolinium complex 
Table I Relaxivity of MRI Contrast Agents

\begin{tabular}{|c|c|c|c|c|c|c|c|c|c|}
\hline \multirow[t]{2}{*}{ Entry } & $r_{1}$ & $r_{1}$ & $r_{2}$ & $r_{2}$ & $B_{0}$ & \multirow[t]{2}{*}{$t[\mathrm{C}]$} & \multirow{2}{*}{$\begin{array}{l}\text { Paramagnet } \\
\text { Content [\%] }\end{array}$} & \multirow[t]{2}{*}{ Size $[\mathrm{nm}]$} & \multirow{2}{*}{$\begin{array}{c}\text { Remark, } \\
\text { Ref. }\end{array}$} \\
\hline & $\mathrm{mM}^{-1} \mathrm{~s}^{-1}$ & $\begin{array}{l}(\mathrm{mg} / \\
\mathrm{mL})^{-1} \mathrm{~s}^{-1}\end{array}$ & $\mathrm{mM}^{-1} \mathrm{~s}^{-1}$ & $\begin{array}{l}(\mathrm{mg} / \\
\mathrm{mL})^{-1} \mathrm{~s}^{-1}\end{array}$ & {$[\mathrm{~T}]$} & & & & \\
\hline \multicolumn{10}{|l|}{ Discrete complexes } \\
\hline GdDOTA-4AMP-F & $7.4-3.9$ & $10-19$ & & & $\mathrm{I} .4$ & 37 & $14 \%(\mathrm{Mw})$ & & {$[40]$} \\
\hline $\begin{array}{l}\text { Gd-NPep-FI (MRI or PET } \\
\text { probe) }\end{array}$ & 21.2 & 16 & & & 1.4 & 37 & $12 \%(M w)$ & & [4I] \\
\hline [GdDO3A-SA-Ga(AAZTA)] & $3.7-10.1$ & $9-24$ & & & 0.47 & 25 & $13 \%(\mathrm{Mw})$ & & [42] \\
\hline $\begin{array}{l}\text { Gd-PCTA-Lys(ZW800-I)- } \\
\text { OAI }\end{array}$ & 5.47 & 6 & & & 9.4 & 37 & $18 \%(M w)$ & 0.31 & [43] \\
\hline \multicolumn{10}{|l|}{ Nanoparticles (NP) } \\
\hline \multicolumn{10}{|l|}{ Commercial SPIONs } \\
\hline Feridex ${ }^{\circledR}$ & 23.9 & & 151.9 & & 3 & 20 & & $80-150$ & {$[36,44]$} \\
\hline Feraheme $^{T M}$ (ferumoxytol) & 10 & 75 & 89 & 667 & $\begin{array}{c}4.7 \\
3\end{array}$ & 37 & $41.21 \% \mathrm{Fe}$ & $17-35 \mathrm{~nm}$ & {$[45,46]$} \\
\hline \multicolumn{10}{|l|}{ New hybrids } \\
\hline MnMEIO & & & 321.6 & 4400 & 1.5 & & $75.25 \mathrm{Mn}+\mathrm{Fe} \%$ & 32 (hydro) & [37] \\
\hline Jarrett2008-ADIO & 14.46 & 129 & 72.55 & 659 & 1.4 & 37 & $50 \%$ & 32.3 & [47] \\
\hline Lee2008-PASP-IO & & & 105.5 & 2134 & 3 & 20 & $\begin{array}{l}72.3 \%(X-\text { ray } \\
\left.\mathrm{Fe}_{3} \mathrm{O}_{4}\right)\end{array}$ & $45 \pm 10$ & [36] \\
\hline DOTA-mSPIO & & & 209 & & 0.47 & & & $\begin{array}{l}20.3 \\
\text { (hydro) }\end{array}$ & [48] \\
\hline EP-2I04R & 41 & & & & 3 & & $\begin{array}{l}\mathrm{Gd} 100000 \mathrm{Da} \\
\text { protein }\end{array}$ & & {$[4 I]$} \\
\hline SPIO_cRGD & & & 101.9 & 204 & 4.7 & 18 & $11.2 \% \mathrm{Fe}$ & 10 & [49] \\
\hline CAN-Magh & 0.2 & 2 & 72 & 601 & VI.5 & & $64.4 \% \mathrm{Fe}$ & $\begin{array}{l}44- \\
55 \text { (hydro) }\end{array}$ & {$[50]$} \\
\hline $\mathrm{DIO} / \mathrm{Cu}$ & 17.1 & & 135.8 & & $\mathrm{I} .4$ & 37 & & 45.7 & [5। $]$ \\
\hline NOTA-OA-IONP & & & 157 & & 4.7 & & & 66 & [34] \\
\hline SPION@PAA & & & 93.8 & & 4.7 & 37 & & & {$[35,52]$} \\
\hline PEM & & & 265.0 & 261 & 3 & & $5.5 \% \mathrm{Fe}$ & 140 & {$[23]$} \\
\hline Fe3O4@AI(OH)3 & 3.7 & 49 & 121.9 & 279 & 3 & & 7.92 & 49.8 & {$[53]$} \\
\hline SDIO & 18.1 & 36 & 95.8 & 194 & 1.4 & 37 & II.34\%Fe & 62.4 & [39] \\
\hline DIO & 15.7 & 49 & 89.2 & 279 & 1.4 & 37 & $17.53 \% \mathrm{Fe}$ & 38.1 & [39] \\
\hline AGulX & 10.3 & & 13.4 & & 1.4 & & $\begin{array}{l}\text { I2.42\% (ICP- } \\
\text { MS) }\end{array}$ & 2.5 (hydro) & {$[54]$} \\
\hline NOTA-IO-Man & & & 449.9 & & & & & $\begin{array}{l}10.12 \\
\text { (hydro) }\end{array}$ & [55] \\
\hline
\end{tabular}


Table I (Continued).

\begin{tabular}{|c|c|c|c|c|c|c|c|c|c|}
\hline \multirow[t]{2}{*}{ Entry } & $r_{1}$ & $r_{1}$ & $r_{2}$ & $r_{2}$ & $B_{0}$ & \multirow[t]{2}{*}{$t\left[{ }^{\circ} \mathrm{C}\right]$} & \multirow{2}{*}{$\begin{array}{l}\text { Paramagnet } \\
\text { Content [\%] }\end{array}$} & \multirow[t]{2}{*}{ Size $[\mathrm{nm}]$} & \multirow{2}{*}{$\begin{array}{l}\text { Remark, } \\
\text { Ref. }\end{array}$} \\
\hline & $\mathrm{mM}^{-1} \mathrm{~s}^{-1}$ & $\begin{array}{l}(\mathrm{mg} / \\
\mathrm{mL})^{-1} \mathrm{~s}^{-1}\end{array}$ & $\mathrm{mM}^{-1} \mathrm{~s}^{-1}$ & $\begin{array}{l}(\mathrm{mg} / \\
\mathrm{mL})^{-1} \mathrm{~s}^{-1}\end{array}$ & {$[\mathrm{~T}]$} & & & & \\
\hline DOTA-IO-GUL & & & 185 & & 9.4 & & & 11.01 & [56] \\
\hline 68Ga-C-IONP & 5.7 & 51.7 & 22.2 & 201.3 & 1.5 & 37 & $50.6 \% \mathrm{Fe}$ & 20.6 & [57] \\
\hline s-SPION25 & & & 953 & & 11.7 & $\mathrm{rt}$ & & 25 & [58] \\
\hline NPs-dopa-PEG-DOTA/RGD & & & 267.5 & 1609 & 7.0 & & $32.5 \% \mathrm{Mn} \& \mathrm{Fe}$ & 26.4 & [38] \\
\hline $\begin{array}{l}\text { NOTA-FA-FI-PEG-PEI-Ac } \\
-\mathrm{Mn} 3 \mathrm{O} 4\end{array}$ & 0.57 & 4.04 & & & 0.5 & 37 & $40 \% \mathrm{Mn}$ & $\begin{array}{l}476.5 \\
\text { (hydro) }\end{array}$ & [59] \\
\hline AGulX & 13.5 & 12 & 18.2 & 16 & 1.4 & 37 & I4\% Gd (Mw) & 4.6 & [60] \\
\hline $\begin{array}{l}\text { SPION-LDOPA-PEG } \\
\text {-MANOTA }\end{array}$ & & & 360 & 3965 & 3 & & $61.5 \% \mathrm{Fe}$ & 119 & [60] \\
\hline $\mathrm{FH}$ & $10-20$ & & $57-60$ & & & & & & [6I] \\
\hline $\begin{array}{l}\text { Au-Fe3O4@PDA-PEG-DTPA } \\
\text {-Gd TI/T2/ dual model }\end{array}$ & 6.14 & & 71.88 & & 3.0 & & $22800 \mathrm{Gd} / \mathrm{NP}$ & 70.89 & [62] \\
\hline
\end{tabular}

characteristics by measuring their acceleration effect $\left(T_{1}\right.$ or $T_{2}$ shortening $-T_{1 / 2}(\mathrm{obs})$ ) with units of millimolar concentration $([\mathrm{Gd}]-\mathrm{mM})$. There is also a diamagnetic factor derived from the natural relaxation rate of water $T_{1 / 2}$ (diam)- Equation 1 .

$$
\mathrm{T}_{1 / 2}(\mathrm{obs})=\mathrm{r}_{1 / 2} *[\mathrm{Gd}]+\mathrm{T}_{1 / 2}(\mathrm{diam})
$$

This way of expressing relaxivity is simple, useful, and can be used to directly evaluate a potential candidate. The calculation of the molarity of the paramagnet is necessary, which is not a problem for discrete molecular complexes. Additionally, the impact of the paramagnet is crucial, however even if its content in the final complex is 20$30 \%$ (for example $28 \% \mathrm{Gd}$ in gadoteric acid) due to the size $(<1 \mathrm{~nm})$ the majority of the mass, a kind of securing ballast is not regarded to be a burden the clearance mechanisms. However, when it comes to NPs the size is already 1-2 orders higher, and taking into account their spatial, mostly globular nature, their weight is already a great difference. For example, a $100 \mathrm{~nm}$ SPION has a mass of about $2.5^{*} 10^{-12} \mathrm{~g}$. For comparison, globulin in the blood can reach a size of $50 \mathrm{~nm}, 10^{-18} \mathrm{~g},{ }^{32}$ while a red blood cell in humans is about $6000 \mathrm{~nm} ;{ }^{33}$ therefore, it is worth normalizing the relaxation enhancement to the mass of the nanomaterials. This is usually not provided in reports, perhaps due to the assumption that the majority of NPs are responsible for the contrast effects. While this is true for chelator-free, poorly-functionalized SPION particles, it is not valid for advanced decoration. For example, Kim reported the use of $16.1 \mathrm{~nm}$ SPION, which after functionalization with oleate acid residues and NOTA chelator, formed $66.3 \mathrm{~nm}$ nanoparticles. ${ }^{34}$ Very similar size growth was observed in Yang's models. ${ }^{35}$ Another challenge to compare the relaxivity recalculated based on the mass of particles is the lack of a paramagnet percentage. To calculate classic relaxivity expressed in $\mathrm{mM}^{-1} \mathrm{~s}^{-1}$, one must know the real paramagnet $(\mathrm{Fe}, \mathrm{Gd}, \mathrm{Mn}, \ldots$ ) content; however, this is not directly provided in most works, or there is often no explanation of how the concentration was determined. Although IC-MS is recommended, it is possible that the researchers assume paramagnets are the main component based only on its mass, such as $\mathrm{Fe}_{3} \mathrm{O}_{4}$. Kim showed that the non-magnetic balance may be huge and, therefore, the results may carry high error; therefore, based on the provided data, as well as the indirect, but very useful and reliable information like thermogravimetric analysis (TGA) that shows the real content of the inorganic matter in probes, we compiled the relaxivity data for comparison and further discussion (Table 1). Most of the reported NPs expressed a higher $T_{2}$ relaxivity than the reference iron-containing drugs, Feridex $^{\circledR}$ and Feraheme ${ }^{\mathrm{TM}}$. The high base relaxivity and 
significant content of magnetic components ( $\mathrm{Fe}, \mathrm{Mn}$ ) resulted in extremely high relaxivities calculated per mass in the range of several thousand, such as in the case of Choi, Shi, and Lee. ${ }^{36-38}$ Comparing two of Tu's NPs SDIO and DIO, it is clear that a similar $T_{2}$ relaxivity calculated from the molarity of iron is $40 \%$ higher as expressed by the entire mass of the NP due to a higher iron content. ${ }^{39}$ Moreover, the smaller size of the more effective species may improve their biocompatibility. The limitation of $r_{2}$ comparison calculated by the classical unit $\mathrm{mM}^{-1} \mathrm{~s}^{-1}$ is evident in the case of two completely different NP: Aryal's USPIONs (initially $5 \mathrm{~nm}$ ), after being covered by poly(lactic-co-glycolic acid), lipids, and polyethylene glycol, had a final size of $140 \mathrm{~nm}$ with an $r_{2}$ of 265 $\mathrm{mM}^{-1} \mathrm{~s}^{-1}$. The multilayer organic-polymeric shell reduced the iron content to $5 \%$, which led to an $r_{2}$ of $261(\mathrm{mg} /$ $\mathrm{mL})^{-1} \mathrm{~s}^{-1}$. In contrast, Shi's NPs with a similar $r_{2}$ $\left[\mathrm{mM}^{-1} \mathrm{~s}^{-1}\right]$ were much smaller. They contained $32.5 \%$ of the magnetic elements, reaching $1609(\mathrm{mg} / \mathrm{mL})^{-1} \mathrm{~s}^{-1}$, which means that its unit mass concentration provided a 6-fold more efficient acceleration of $T_{2}$. There are many ways to compare the available data, but our goal is to investigate how the determined physical properties allow for a preliminary estimation of the intended effect.

\section{PET Probes}

PET imaging agents fall into two categories:

i) agents used for metabolic imaging based on small molecules, such as glucose or amino acids, which are rapidly taken up into cells by transporters and metabolized. Many of these are analogs of native small molecules and are designed to undergo limited metabolism and are afterwards retained within particular cells;

ii) agents used for receptor imaging based on monoclonal antibodies, antibody fragments, or engineered protein scaffolds.

The most commonly used PET radiotracer is $\left[{ }^{18} \mathrm{~F}\right]$ 2-fluoro-2-deoxy-glucose $\left({ }^{18} \mathrm{~F}\right.$-FDG). It is a glucose ana$\log$ that accumulates in tissues with increased glucose metabolism; therefore, increased radiotracer uptake can usually be found in high-grade tumors. ${ }^{63}$ A significant drawback of ${ }^{18} \mathrm{~F}$-FDG is its lack of specificity and high physiological accumulation in organs such as the brain or heart. Receptor-based ligands specifically bind to antigens on the cell membrane. The selection of an optimal targeting agent is based on several characteristics, including its specificity, affinity, metabolism, and clearance of the molecule.
Table 2 PET Isotopes and Their Half-Lives

\begin{tabular}{|l|l|l|l|l|l|l|l|}
\hline Isotope & ${ }^{11} \mathbf{C}$ & ${ }^{68} \mathbf{G a}$ & ${ }^{18} \mathbf{F}$ & ${ }^{64} \mathbf{C u}$ & ${ }^{69} \mathbf{G e}$ & ${ }^{89} \mathbf{Z r}$ & ${ }^{124} \mathbf{I}$ \\
\hline Half-life & $\begin{array}{l}20.4 \\
\min \end{array}$ & $\begin{array}{l}68 \\
\min \end{array}$ & $\begin{array}{l}\mathrm{II} \\
\mathrm{min}\end{array}$ & $\begin{array}{l}12.7 \\
\mathrm{~h}\end{array}$ & $\begin{array}{l}39.5 \\
\mathrm{~h}\end{array}$ & $78 \mathrm{~h}$ & $\begin{array}{l}100 \\
\mathrm{~h}\end{array}$ \\
\hline
\end{tabular}

Designing a PET imaging probe is a complex process. The choice of a radioisotope, linker, and targeting vector must be carefully selected, as each can alter the radiopharmaceutical properties and, thus, the imaging results. Choosing a specific isotope suitable for a probe depends on its availability, half-life, and the chemical characteristics of the nuclide. The selected radioisotope should decay mostly through positron emission or electron capture, so the annihilation of a positron-electron pair may occur. The most frequently used PET isotopes are ${ }^{11} \mathrm{C},{ }^{18} \mathrm{~F},{ }^{68} \mathrm{Ga},{ }^{89} \mathrm{Zr},{ }^{124} \mathrm{I}$, and ${ }^{64} \mathrm{Cu}$, all of which have different chemical properties (Table 2). The radionuclide half-life needs to match the biological half-life of the targeting molecule and should be long enough to allow for radiolabeling and imaging procedures. Finally, depending on the scientific question at hand, the targeting vector's molecular weight, radiopharmaceutical clearance characteristics, and binding affinity must be optimized. In practice, imaging agents based on intact antibodies suffer due to their large molecular size, slow pharmacokinetics, and long circulation times (up to 3 weeks); therefore, they need to be radiolabeled with longer-lived radionuclides (eg, $\left.{ }^{89} \mathrm{Zr},{ }^{124} \mathrm{I}\right)$. These are lessideal for clinical imaging due to higher associated radiation doses and longer wait times for imaging. Smaller protein scaffolds have much shorter circulation times (hours rather than weeks), deeper penetration into tissue, and they can be labeled with more clinically-relevant shorter-lived PET radionuclides, which enable same-day imaging; however, they may have lower affinities and typically display lower overall tumor uptake than full antibodies.

\section{Real Problems}

\section{Probe Preparation}

Obtaining such complex molecules as bimodal probes (Table 3) involves many synthetic steps. The preparation of a nanostructure, surface functionalization, and the attachment of a targeting molecule are often long and multi-stage processes. ${ }^{34,38-40,49,50,53,57,59,60,62}$ More 
reaction steps require more time from the operator and might affect the reproducibility; therefore, modular and one-pot syntheses are gaining in popularity due to faster tracer preparation times and often lower costs. Moon et al reported shorter one-/two-step encapsulation methods for the synthesis of iron oxide with DOTA-SA and GUL-SA moieties. ${ }^{56}$ The first step of the synthesis - the preparation of amphiphiles for the IO core functionalization-gave a yield of $45 \%$ (for two steps) and 36\% (for one step). The second part involved attaching amphiphiles to SPION, which had a yield of $85 \%$.

Another team proposed a one-step modular solution for the synthesis of three matrices based on different nanostructures: SPION, AuNPs, and upconverting nanophosphors (UCNPs), containing aliphatic side chains. ${ }^{64}$ Five separate modules based on BSA (bovine serum albumin), with different chelators (DOTA or DFO) or optical imaging dye (Alexa647) and a maleimide moiety, were prepared. By choosing a nanocore and a BSA-based module or modules, one-step functionalization was carried out employing van der Waals interactions between BSA and the functional groups present in the aliphatic chains of the nanostructures. This approach allowed for the creation of a library of thirteen different multimodal probes. Moreover, Yang et al demonstrated the ability of ferritin to reversibly disassemble upon pH changes. ${ }^{65}$ At low pH (2-3), melanin NPs (MNPs) and iron ions were added to the unfolded nanostructure. When the mixture was put into an alkaline environment $(\mathrm{pH}=8)$, the ferritin structure encapsulated the MNPs and iron ions. The radiolabeling of ${ }^{64} \mathrm{Cu}$ was carried out without reopening the structure, and the ions penetrated the interior through pores. The in vivo imaging post-probe injection showed accumulation in the target. The authors highlighted the prospect of using this method to load other ions or targeting motifs; however, a concern is that the low-pH environment of tumor tissues may cause partial disassembly of the probe's structure. This would be a disadvantageous effect for diagnostics, but it may have therapeutic potential. Other interesting studies confirmed the benefits of using chelator-free microwave-assisted heating for the one-step preparation of dextran-coated SPIONs containing the ${ }^{64} \mathrm{Cu}$ isotope. ${ }^{51}$ The authors demonstrated that the probe was less prone to radionuclide loss than when attaching copper via a chelator.

\section{Coating}

It is common to coat the surface of inorganic nanostructures with various polymers to increase their dispersibility or to incorporate functional groups that can be further modified.
Poly(ethylene glycol) (PEG) coatings have been shown to increase the stability of probes in vivo and protect them from undesirable non-specific binding due to stealth effects. There are numerous reports on nanostructures coated with this polymer. ${ }^{23,34,36,49,50,52,59,62,66}$ To achieve colloidal stability, the surface of nanostructures was coated with dextran, which increased the probe's stability in water, its biocompatibility, and its blood retention time. ${ }^{39,47,51,57,61,67,68}$ In addition, the PAA (poly(acrylic acid) (PAA), ${ }^{35}$ serum albumin, ${ }^{37}$ and methoxy-PEG $(\mathrm{MPEG})^{58}$ were also used to increase the colloidal stability and water solubility.

\section{Radiolabeling}

Apart from the modular/single-pot syntheses described above, radionuclides can be attached to molecules via both chelator and chelator-free methods. In the first approach, it is necessary to introduce a ligand into the structure or on the surface of the probe. The most commonly used chelators are: DFO for ${ }^{89} \mathrm{Zr}^{45,69}$ and for ${ }^{64} \mathrm{Cu}$ : DOTA, ${ }^{23,36,38,39,47,48,56,70}$ DTCBP, ${ }^{53,68}$ NODAGA, ${ }^{60}$ MANOTA $^{66}$ and NOTA. ${ }^{49,59}$ Gallium-68 was chelated with NOTA, ${ }^{34}$ NODA, ${ }^{50,54}$ and TRAP. ${ }^{71}$

In the chelator-free approach, ${ }^{89} \mathrm{Zr}$ can be directly conjugated to the feraheme (dextran-coated SPIONs) surface using heat-induced radiolabeling. ${ }^{61,67}$ The sorption of germanium ions onto the iron oxide surface at $\mathrm{pH}$ from 4 to 8 has also been reported. ${ }^{52}$ Radiolabeling of bimodal probes with non-metallic radionuclides such as ${ }^{124} \mathrm{I}$ or ${ }^{11} \mathrm{C}$ requires the formation of covalent bonds between the molecule and isotope. This can be achieved by surface functionalization with albumin. ${ }^{37,72}$

\section{Cytotoxicity}

MRI is considered to be a relatively safe method compared to other imaging techniques, but MR CAs may have a negative impact on living organisms. For example, iron oxide NPs can lead to local and systemic inflammation, oxidative stress, and genotoxicity. ${ }^{73,74}$ The scale of these effects depends on the NP core size, synthesis method, type of coating, and hydrodynamic radius. ${ }^{75}$ Moreover, $\mathrm{Gd}$ was shown to cause nephrogenic systemic fibrosis. Although this effect was strongly reduced by applying restrictive administration guidelines, ${ }^{76}$ the deposition of $\mathrm{Gd}$ in the brain and other tissues has been reported. ${ }^{77-80}$ Recently proposed MRI-PET bimodal probes (Table 3) display biocompatibility and can possibly synergistically cancel or amplify deleterious effects; therefore, every 
Table 3 PET/MRI Bimodal Probes

\begin{tabular}{|c|c|c|c|c|c|c|c|c|}
\hline Molecule & Isotope & Paramagnetic & $\begin{array}{l}\text { Activity } \\
\text { per Inj. }\end{array}$ & Dose & $\begin{array}{l}\text { Target } \\
\text { (Targeting } \\
\text { Vector) }\end{array}$ & Accumulation $^{a}$ & Clearance $^{b}$ & Ref \\
\hline Liposome & ${ }^{89} \mathrm{Zr}$ & Gd & $35-40 \mu \mathrm{Ci}$ & $\begin{array}{l}2.78 \mu \mathrm{mol} \\
\text { Gd-DTPA } \\
\text {-BiSA }\end{array}$ & $\begin{array}{l}\text { Neuroendocrine } \\
\text { tumor: SSTr2- } \\
\text { postive } \\
\text { transduced cell } \\
\text { (OCT) }\end{array}$ & $\begin{array}{l}\text { RES - I8\% ID/g } \\
\text { Bones - I2\% ID/g } \\
\text { Tumor - 3.5-5\%ID/g } \\
\text { @ } 50 \mathrm{~h} \mathrm{pi}\end{array}$ & $\begin{array}{l}>96 \\
h \text { through } \\
\text { RES }\end{array}$ & [45] \\
\hline PLGA/PEG & ${ }^{64} \mathrm{Cu}$ & SPION & $100 \mu \mathrm{Ci}$ & $\begin{array}{l}0.1 \mathrm{mg} \\
\text { SPION }\end{array}$ & Breast tumor & $\begin{array}{l}\text { Tumor - } 3.5 \pm 0.25 \% \\
\text { ID/g } \\
\text { Liver } 22.0 \pm 6.0 \% \\
\text { ID/g } \\
\text { Spleen, kidneys - } 5 \% \\
\text { each } \\
\text { @ } 20 \text { h pi }\end{array}$ & $\begin{array}{l}50 \mathrm{~h} \\
\text { (from } \\
\text { blood) } \\
\text { Renal } \\
\text { excretion of } \\
{ }^{64} \mathrm{Cu}\end{array}$ & [23] \\
\hline $\mathrm{FH}$ & ${ }^{89} \mathrm{Zr}$ & SPION & $\begin{array}{l}185-195 \\
\mu C i\end{array}$ & $\begin{array}{l}\sim 0.20- \\
0.21 \mathrm{mg} \\
\mathrm{Fe}\end{array}$ & $\begin{array}{l}\text { Muscle } \\
\text { inflammation }\end{array}$ & $\begin{array}{l}\text { Inflamed muscle - } \\
0.95-0.12 \% \mathrm{ID} / \mathrm{g} \\
\text { Liver - } 101.93 \% \mathrm{ID} / \mathrm{g} \\
\text { Spleen } 132.96 \% \mathrm{ID} / \mathrm{g} \\
@ 120 \mathrm{~h} \text { pi } \\
\text { Inflamed-to-control } \\
\text { muscle ratio at I20 } \\
\text { h pi: } 9.64 \pm 2.49\end{array}$ & $>120 h$ & [67] \\
\hline $\begin{array}{l}\text { PAA modified } \\
\text { SPIONs }\end{array}$ & ${ }^{69} \mathrm{Ge}$ & SPION & $\begin{array}{l}50 \mu \mathrm{Ci} \\
10 \mu \mathrm{Ci} \\
\text { (paw inj.) }\end{array}$ & $\begin{array}{l}7.77 \mathrm{mM} \\
\mathrm{Fe}\end{array}$ & SLN & $\begin{array}{l}\text { Liver - I3\%ID/g } \\
\text { Spleen 9\%ID/g } \\
@ 36 \text { h pi } \\
\text { SLN - 28\%ID/g (paw } \\
\text { inj.) @ 20h pi }\end{array}$ & $>36 \mathrm{~h}$ & [52] \\
\hline $\begin{array}{l}\text { PAA modified } \\
\text { SPIONs }\end{array}$ & *As & SPION & $\begin{array}{l}148.5 \mu \mathrm{Ci} \\
8 \mathrm{I} \mu \mathrm{Ci} \\
\text { (paw inj.) }\end{array}$ & $\begin{array}{l}40 \mu \mathrm{L}, \\
7.77 \mathrm{mM} \\
\text { of } \mathrm{Fe}\end{array}$ & SLN & $\begin{array}{l}\text { Liver - } 25 \text { and II \% } \\
\text { ID/g } \\
\text { Bladder - I } 2 \text { and } \\
3.8 \% I D / g \\
@ 0.5 \text { h and } 20 \text { h pi } \\
\text { SLN I } 2.5 \text { and I3.2\% } \\
\text { ID/g (paw inj.) @ } 2.5 \\
\text { and I5 h pi }\end{array}$ & No data & [35] \\
\hline MnMEIO & ${ }^{124} I$ & $\mathrm{MnFe}_{2} \mathrm{O}_{4}$ & $\begin{array}{l}110 \mu \mathrm{Ci} \\
335 \mu \mathrm{Ci} \\
\text { (paw inj.) }\end{array}$ & $\begin{array}{l}80 \mu g(\mathrm{Mn} \\
+\mathrm{Fe} \text { inj.) } \\
229 \mathrm{mg} / \mathrm{kg} \\
(\mathrm{Mn}+\mathrm{Fe})\end{array}$ & SLN & No data & $>144 \mathrm{~h}$ & [37] \\
\hline $\begin{array}{l}\mathrm{MnFe} 2 \mathrm{O} 4 \text { and } \\
\mathrm{Fe} 3 \mathrm{O} 4\end{array}$ & ${ }^{18} \mathrm{~F}$ & $\mathrm{Fe}$ & $25 \mu \mathrm{Ci}$ & $60 \mathrm{mg} \mathrm{Fe}$ & & & & [53] \\
\hline
\end{tabular}

(Continued) 
Table 3 (Continued).

\begin{tabular}{|c|c|c|c|c|c|c|c|c|}
\hline Molecule & Isotope & Paramagnetic & $\begin{array}{l}\text { Activity } \\
\text { per Inj. }\end{array}$ & Dose & $\begin{array}{l}\text { Target } \\
\text { (Targeting } \\
\text { Vector) }\end{array}$ & Accumulation $^{\mathbf{a}}$ & Clearance $^{b}$ & Ref \\
\hline $\begin{array}{l}\text { NOTA-FA- } \\
\text { PEG-PEI-Ac- } \\
\text { Mn3O4 }\end{array}$ & ${ }^{64} \mathrm{Cu}$ & $\mathrm{Mn}_{3} \mathrm{O}_{4}$ & $200 \mu \mathrm{Ci}$ & $\begin{array}{l}2.5 \mathrm{mg} / \\
\mathrm{mL}, \text { inj. } \\
200 \mu \mathrm{L}\end{array}$ & $\begin{array}{l}\text { Folate receptor } \\
\text { in cervical cancer } \\
\text { (folic acid) }\end{array}$ & $\begin{array}{l}\text { Tumor - I.5\%ID/g } \\
\text { Liver } 6 \% \mathrm{ID} / \mathrm{g} \\
\text { Kidneys, spleen } \\
\sim 2.5 \% \mathrm{ID} / \mathrm{g} \\
@ 24 \mathrm{~h} \mathrm{pi} \\
\text { Tumor-to-muscle } \\
\text { ratio: } 5.35 \pm 0.3 \mathrm{I} \text { at } \\
18 \mathrm{~h}\end{array}$ & $>24 \mathrm{~h}$ & [59] \\
\hline $\begin{array}{l}\text { PEGylated } \\
\text { phospholipids }\end{array}$ & ${ }^{64} \mathrm{Cu}$ & SPION & $100 \mu \mathrm{Ci}$ & $\begin{array}{l}10 \mathrm{mg} \\
\mathrm{Fe} / \mathrm{kg} \\
\text { body } \\
\text { weight }\end{array}$ & & $\begin{array}{l}\text { Liver, spleen }-3 \mathrm{I} \pm \\
\text { I8\%ID/g } \\
@ \text { Ih pi }\end{array}$ & $>24 h$ & [48] \\
\hline $\begin{array}{l}\text { Cu-Dota/ } \\
\text { Dextran } \\
\text { coated SPION }\end{array}$ & ${ }^{64} \mathrm{Cu}$ & $\begin{array}{l}\text { SPION } \\
\text { Gd }\end{array}$ & $\begin{array}{l}20-25 \\
\mu \mathrm{Ci} / g\end{array}$ & $\begin{array}{l}18-20 \mathrm{mg} \\
\mathrm{Fe} / \mathrm{kg}\end{array}$ & $\begin{array}{l}\text { Vascular } \\
\text { inflammation/ } \\
\text { receptor SR-A } \\
\text { (Mal-BSA) }\end{array}$ & & $>24 \mathrm{~h}$ & {$[39,45,97]$} \\
\hline $\begin{array}{l}\text { SPION-NOTA } \\
\text {-Ga }\end{array}$ & ${ }^{68} \mathrm{Ga}$ & SPION & $100 \mu \mathrm{Ci}$ & $\begin{array}{l}\text { I } \mathrm{mg} / \mathrm{mL} \\
\text { of IONP } \\
\text { or } \\
\text { OAelONP }\end{array}$ & $\begin{array}{l}\text { Colon cancer } \\
\text { cells (oleanic } \\
\text { acid) }\end{array}$ & $\begin{array}{l}\text { Tumor } 3.07 \pm 0.76 \% \\
\text { ID/g } \\
\text { Liver - biggest } \\
\text { uptake } \\
@ \text { Ih pi }\end{array}$ & $>4 \mathrm{~h}$ & [33] \\
\hline $\begin{array}{l}\text { DOTA-RGD- } \\
\text { PASP }\end{array}$ & ${ }^{64} \mathrm{Cu}$ & SPION & $100 \mu \mathrm{Ci}$ & $300 \mu \mathrm{g} \mathrm{Fe}$ & $\begin{array}{l}\text { Integrin } \alpha v \beta 3 \\
\text { (RGD) }\end{array}$ & $\begin{array}{l}\text { Tumor - } 10.1 \pm 2.1 \% \\
\text { ID/g } \\
\text { Liver - } 22.6 \pm 2.9 \% \\
\text { ID/g } \\
\text { Kidneys - } 4.9 \pm 0.8 \% \\
\text { ID/g } \\
@ 4 \mathrm{~h} \mathrm{pi}\end{array}$ & $>4 \mathrm{~h}$ & [36] \\
\hline $\begin{array}{l}\text { PEGylated } \\
\mathrm{MnFe}_{2} \mathrm{O} 4\end{array}$ & ${ }^{64} \mathrm{Cu}$ & $\mathrm{MnFe}_{2} \mathrm{O}_{4}$ & $100 \mu \mathrm{Ci}$ & $200 \mu \mathrm{g} \mathrm{Fe}$ & $\begin{array}{l}\text { Integrin } \alpha v \beta 3 \\
\text { (RGD) }\end{array}$ & $\begin{array}{l}\text { Liver - 27\%ID/g } \\
\text { Spleen - 8\%ID/g } \\
\text { Kidneys - 7\%ID/g } \\
\text { Tumor- 6\%ID/g } \\
\text { @ 6h pi }\end{array}$ & $>6 \mathrm{~h}$ & [38] \\
\hline $\begin{array}{l}\text { PEG-PLGA- } \\
\text { SPION }\end{array}$ & ${ }^{68} \mathrm{Ga}$ & SPION & $\begin{array}{l}200 \pm \\
64.8 \mu \mathrm{Ci}\end{array}$ & $\begin{array}{l}3.8 \pm \mathrm{I} .3 \\
\mu \mathrm{g} \text { of } \\
\mathrm{Fe}_{2} \mathrm{O}_{3}\end{array}$ & $\begin{array}{l}\text { Pancreatic ductal } \\
\text { adenocarcinoma }\end{array}$ & $\begin{array}{l}\text { Liver - I.7\%ID/g } \\
\text { Spleen - } 2.1 \% \mathrm{ID} / \mathrm{g} \\
@>20 \mathrm{~min} \mathrm{pi}\end{array}$ & No data & [50] \\
\hline DOTA-GUL & ${ }^{68} \mathrm{Ga}$ & SPION & $275.4 \mu \mathrm{Ci}$ & $\begin{array}{l}200 \mu \mathrm{M} \\
\text { DOTA-IO } \\
\text {-GUL }\end{array}$ & $\begin{array}{l}\text { Prostate (PSMA - } \\
\text { GUL) }\end{array}$ & Tumor specificity & No data & [56] \\
\hline $\begin{array}{l}\text { TRAP } \\
\text { (HMDA- } \\
\text { DOTA) }\end{array}$ & ${ }^{68} \mathrm{Ga}$ & Gd & $727 \mu \mathrm{Ci}$ & $130 \mathrm{mg} / \mathrm{kg}$ & & $\begin{array}{l}\text { Kidneys } \\
@ 25 \text { min pi }\end{array}$ & No data & [7I] \\
\hline
\end{tabular}

(Continued) 
Table 3 (Continued).

\begin{tabular}{|c|c|c|c|c|c|c|c|c|}
\hline Molecule & Isotope & Paramagnetic & $\begin{array}{l}\text { Activity } \\
\text { per Inj. }\end{array}$ & Dose & $\begin{array}{l}\text { Target } \\
\text { (Targeting } \\
\text { Vector) }\end{array}$ & Accumulation $^{\mathbf{a}}$ & Clearance $^{b}$ & Ref \\
\hline $\begin{array}{l}\text { Dextran } \\
\text { coated SPION }\end{array}$ & ${ }^{68} \mathrm{Ga}$ & SPION & $405 \mu \mathrm{Ci}$ & $0.1 \mathrm{Img} \mathrm{Fe}$ & $\begin{array}{l}\text { Melanoma } \\
\text { (RGD) }\end{array}$ & $\begin{array}{l}\text { Tumor, heart - } 9 \% \\
\text { ID/g each } \\
\text { Spleen, kidneys I0\% } \\
\text { ID/g } \\
\text { Liver - 25\%ID/g }\end{array}$ & No data & [57] \\
\hline $\begin{array}{l}\text { BP-based } \\
64 \mathrm{Cu}-(\mathrm{dtcbp}) 2 \\
\text { and dextran- } \\
\text { coated SPION }\end{array}$ & ${ }^{64} \mathrm{Cu}$ & SPION & $54 \mu \mathrm{Ci}$ & $44 \mathrm{mg} \mathrm{Fe}$ & SLN & SLN & No data & [68] \\
\hline $\begin{array}{l}-\mathrm{COOH} \text { and - } \\
\mathrm{NH} 2 \\
\text { functionalized } \\
\text { SPION }\end{array}$ & ${ }^{11} \mathrm{C}$ & SPION & $100 \mu \mathrm{Ci}$ & & & Liver & $>5 \mathrm{~h}$ & [72] \\
\hline $\begin{array}{l}\text { Silicone- } \\
\text { DOTAGA-Gd }\end{array}$ & $\begin{array}{l}{ }^{64} \mathrm{Cu} \\
{ }^{68} \mathrm{Ga}\end{array}$ & Gd & $270 \mu \mathrm{Ci}$ & & & $\begin{array}{l}\text { Kidneys - 35\%ID/g } \\
\text { Liver - 15\%ID/g } \\
\text { Spleen - 5\%ID/g } \\
\text { Tumor - 2\%ID/g } \\
\text { @ } 24 \text { h pi }\end{array}$ & $\begin{array}{l}>24 \mathrm{~h} \\
\text { Renal }+ \\
\text { hepatic } \\
\text { clearance }\end{array}$ & [60] \\
\hline $\begin{array}{l}\text { LDOPA-PEG- } \\
\text { MANOTA }\end{array}$ & ${ }^{64} \mathrm{Cu}$ & SPION & $\begin{array}{l}67.5-100 \\
\mu \mathrm{Ci}\end{array}$ & $\begin{array}{l}0.8-1.2 \\
\mu \mathrm{mol} \mathrm{Fe}\end{array}$ & & $\begin{array}{l}\text { Liver - 9\%ID/g } \\
\text { Lungs, spleen- 6\% } \\
\text { ID/g each } \\
\text { Kidneys 5\% ID/g } \\
\text { @ 48h pi }\end{array}$ & $>48 \mathrm{~h}$ & [66] \\
\hline $\begin{array}{l}\text { DOTAGA-Gd } \\
+ \text { NODAGA- } \\
\text { Ga }\end{array}$ & ${ }^{68} \mathrm{Ga}$ & Gd & $25 \mu \mathrm{Ci}$ & $\begin{array}{l}20 \mu \mathrm{mol} \\
\text { AGulX }\end{array}$ & & Kidneys, bladder & $>2 \mathrm{~h}$ & [54] \\
\hline $\begin{array}{l}{ }^{89} \mathrm{Zr} \text {-DFO- } \\
\text { labelled } \\
\text { ferumoxytol }\end{array}$ & ${ }^{89} \mathrm{Zr}$ & SPION & $35 \mu \mathrm{Ci}$ & $\begin{array}{l}0.25 \mathrm{mg} \\
\mathrm{Fe}\end{array}$ & $\begin{array}{l}\text { Tumor-draining } \\
\text { lymph nodes, } \\
\text { prostate }\end{array}$ & $\begin{array}{l}\text { Liver - } 23 \% \text { ID/g } \\
\text { Lymph nodes }>40 \% \\
\text { ID/g } \\
@ 24 \text { h pi }\end{array}$ & $>48 \mathrm{~h}$ & [45] \\
\hline $\begin{array}{l}\text { EP-2I04R } \\
\text { (DOTA) }\end{array}$ & ${ }^{64} \mathrm{Cu}$ & Gd & $\begin{array}{l}530 \pm \\
186 \mu \mathrm{Ci}\end{array}$ & $\begin{array}{l}46 \mathrm{mmol} \\
\mathrm{Gd} \text { per kg }\end{array}$ & $\begin{array}{l}\text { Fibrin, (six } \\
\text { amino-acid cyclic } \\
\text { peptide) }\end{array}$ & & $>2 h$ & {$[41,98]$} \\
\hline $\begin{array}{l}\text { DOX } \\
\text { conjugated } \\
\text { SPION }\end{array}$ & ${ }^{64} \mathrm{Cu}$ & SPION & $\begin{array}{l}135-270 \\
\mu C i\end{array}$ & & $\begin{array}{l}\text { Integrin } \alpha v \beta 3 \\
\text { (RGD) }\end{array}$ & $\begin{array}{l}\text { Tumor } 5.6 \pm \\
\mathrm{I} .7 \% \mathrm{ID} / \mathrm{g} \\
\text { Liver } 9.7 \pm 2.7 \% \mathrm{ID} / \mathrm{g} \\
@ 6 \mathrm{~h} \mathrm{pi}\end{array}$ & $>48 \mathrm{~h}$ & [49] \\
\hline $\begin{array}{l}\text { NOTA-IO- } \\
\text { Man }\end{array}$ & ${ }^{68} \mathrm{Ga}$ & SPION & $324 \mu \mathrm{Ci}$ & & SLN (Man-SA) & SLN accumulation & No data & [55] \\
\hline $\begin{array}{l}\text { Gadofullerene- } \\
\text { PEG-RGD }\end{array}$ & $\begin{array}{l}{ }^{68} \mathrm{Ga}, \\
{ }^{89} \mathrm{Zr}\end{array}$ & Gd & $432 \mu \mathrm{Ci}$ & $\begin{array}{l}20 \mu \mathrm{mol} \\
\mathrm{Gd}\end{array}$ & $\begin{array}{l}\text { Integrin } \alpha v \beta 3 \\
\text { (RGD) }\end{array}$ & $\begin{array}{l}\text { Tumor } 2.4 \pm 0.2 \% \\
\text { ID/g } \\
@ 48 \text { h pi }\end{array}$ & $>720 \mathrm{~h}$ & [95] \\
\hline
\end{tabular}


Table 3 (Continued).

\begin{tabular}{|c|c|c|c|c|c|c|c|c|}
\hline Molecule & Isotope & Paramagnetic & $\begin{array}{l}\text { Activity } \\
\text { per Inj. }\end{array}$ & Dose & $\begin{array}{l}\text { Target } \\
\text { (Targeting } \\
\text { Vector) }\end{array}$ & Accumulation $^{\mathbf{a}}$ & Clearance $^{b}$ & Ref \\
\hline $\begin{array}{l}{ }^{89} \text { Zr-DFO- } \\
\text { RGD-BSA- } \\
\text { SPION }\end{array}$ & ${ }^{89} \mathrm{Zr}$ & SPION & $\mathrm{I} \mathrm{mCi}$ & & $\begin{array}{l}\text { Integrin } \alpha v \beta 3 \\
\text { (RGD) }\end{array}$ & $\begin{array}{l}\text { Tumor I.5\%ID/g } \\
\text { Liver 22\%ID/g } \\
\text { @72 h pi }\end{array}$ & $>72 \mathrm{~h}$ & [64] \\
\hline $\begin{array}{l}\text { Melanin- } \\
\text { apoferritin }\end{array}$ & ${ }^{64} \mathrm{Cu}$ & $\mathrm{Fe}$ & $100 \mu \mathrm{Ci}$ & $\begin{array}{l}10 \mathrm{nmol} \\
\text { of NP }\end{array}$ & $\begin{array}{l}\text { Colon cancer } \\
\text { cells (TfRI) }\end{array}$ & $\begin{array}{l}\text { Tumor } 7.34 \pm 0.93 \% \\
\text { ID/g } \\
\text { @4 h pi }\end{array}$ & $>26 \mathrm{~h}$ & [65] \\
\hline
\end{tabular}

Notes: ${ }^{a} @ \mathrm{Xh}$ pi $=$ at $\mathrm{X}$ hours post-injection. ${ }^{\mathrm{b}}>$ "X” means, that biodistribution or accumulation data is available only to certain time post-injection. $* 7 \mathrm{I}, 72,74,76$.

probe with clinical potential must be tested for its cytotoxicity in vitro and in vivo. Unfortunately, the majority of probes reported so far have only been tested in vitro. In vitro testing methods may be useful because they are costefficient, but extrapolating data to in vivo models is not straightforward. Some efforts have been made to compare the probe concentrations tested in vitro with the equivalent doses administered in vivo. (Table 4). The biggest challenge in performing these tests is the lack of information about the molar mass of the investigated probes. Consequently, it is impossible to convert the molar concentration to the mass of a potentially toxic paramagnetic agent.

For example, ${ }^{64} \mathrm{Cu}$-USPIO-PLGA, a polymer-based agent containing paramagnetic iron oxide and labeled with ${ }^{64} \mathrm{Cu}$, was tested in vitro in the $\mathrm{Fe}$ concentration range of $0.06-270 \mu \mathrm{M}$. The assessed cell viability was $\sim 90 \%$, even for the highest conjugate concentration, confirming the biocompatibility of the polymer base. The iron concentration of the same probe injected in vivo was 14 $\mu \mathrm{M}$, which was within the in vitro-tested concentration range. ${ }^{23}$ The cytotoxicity assay of another probe, $\mathrm{Fe}_{3} \mathrm{O}_{4}$ -LDOPA-PEG-MANOTA showed cell viability of 80 $90 \%$ within the concentration range of $2.34-300 \mu \mathrm{g} / \mathrm{mL}{ }^{66}$ But, in this case, there was not sufficient data to compare the in vitro and in vivo results, as only the amount of injected iron $(0.8-1.2 \mu \mathrm{mol} \mathrm{Fe})$, not its molar concentration, was provided.

${ }^{68} \mathrm{Ga}$-C-IONP did not show cytotoxicity in vitro at concentrations as high as $100 \mu \mathrm{g} / \mathrm{mL}$, but the concentration injected in vivo was 11 times greater $(1.1 \mathrm{mg} / \mathrm{mL}){ }^{57}$ The cytotoxicity of another probe, Magh-1-PNPs-NODA, was tested using different amounts $(3-6 \mu \mathrm{g})$ of $\mathrm{Fe}$ on different human cell lines. The results showed a $\sim 50 \%$ decrease in the cell proliferation rate when the highest concentration was used. ${ }^{50}$ Also, iron oxide NPs modified with oleic acid $\left({ }^{68} \mathrm{Ga}\right.$-NOTA-OA-IONP) were tested in a wide spectrum of molar concentrations $0.05-515 \mathrm{mM}$

Table 4 Doses of Bimodal Probes Injected in vivo Compared with the Amounts Tested for Cytotoxicity in vitro

\begin{tabular}{|c|c|c|c|}
\hline Bimodal Probe & Injected in vivo & $\begin{array}{l}\text { Tested } \\
\text { in vitro }\end{array}$ & Ref \\
\hline 64Cu-USPIO-PLGA & $0.73 \mu \mathrm{g} \mathrm{Fe} / \mathrm{mL}$ & $\begin{array}{l}3.35-15 \mu g \\
\mathrm{Fe} / \mathrm{mL}\end{array}$ & [23] \\
\hline Fe3O4- LDOPA-PEG-MANOTA-64Cu & $0.8-1.2 \mu \mathrm{mol}$ Fe (74-III $\mu \mathrm{g}$ SPION*) & $0.3 \mathrm{mg} \mathrm{Fe} / \mathrm{mL}$ & [66] \\
\hline Magh-I-PNPs-NODA & $3.8 \mu \mathrm{g} \mathrm{Fe}$ in $300 \mu \mathrm{L}(12.8 \mu \mathrm{g} / \mathrm{mL})$ & $3-6 \mu \mathrm{g} \mathrm{Fe}$ & [50] \\
\hline 68Ga-C-IONP & I.I mg Fe/mL & $100 \mu \mathrm{g} \mathrm{Fe} / \mathrm{mL}$ & [57] \\
\hline 68Ga-NOTA-OA-IONP & $\mathrm{I} \mathrm{mg} I \mathrm{ONP} / \mathrm{mL}$ & $\begin{array}{l}0.5-512 \mathrm{mM} \\
\text { IONP }\end{array}$ & [34] \\
\hline 68Ga-AGulX & Not injected & $3 \mathrm{mM} \mathrm{Fe}$ & [58] \\
\hline
\end{tabular}

Note: *Calculated based on TGA. 
and were shown to be toxic at concentrations greater than $64 \mathrm{mM} .{ }^{34}$ SPIONs-based $\left({ }^{64} \mathrm{Cu}\right.$ and $\left.{ }^{68} \mathrm{Ga}\right)$ bimodal probes containing $3 \mathrm{mM}$ Fe demonstrated no cytotoxicity. ${ }^{58}$

The assessment of bimodal probe cytotoxicity remains a major problem during their in vitro characterization, and more studies are needed to fully elucidate their behavior in vivo.

\section{Half-Life}

The use of isotopes with a shorter half-life requires quicker labeling procedures (Table 2).

For example, ${ }^{11} \mathrm{C}$ is useful for probing the kinetics of certain small molecules, but its short half-life (20.4 min) requires rapid preparation and purification procedures. A protocol for attaching ${ }^{11} \mathrm{C}$ to surface-functionalized nanostructures was published by Sharma et al, who trapped gaseous $\left[{ }^{11} \mathrm{C}\right] \mathrm{CH}_{3} \mathrm{I}$, purified it, and washed it multiple times within c.a. $30 \mathrm{~min}$. The decay-corrected RY depended on the tested NPs and was in the range of $0.3-7.6 \%$. Of note, the quality control steps proposed in the paper still need to be modified and evaluated in preclinical and clinical studies, which might affect the final obtained activity. $^{72}$

${ }^{68} \mathrm{Ga}$ has a half-life of $68 \mathrm{~min}$ and decays by $89 \%$ through positron emission. ${ }^{81}$ Probes radiolabeled with this isotope are routinely used for imaging myocardial perfusions and functions, blood flow, renal or liver functions, and cancer diagnosis. ${ }^{82-87}$ The half-life of ${ }^{68} \mathrm{Ga}$ is well-matched to the pharmacokinetics of agents targeting somatostatin, ${ }^{88}$ bombesin, ${ }^{89}$ and melanocortin 1 receptors. ${ }^{90}$ As radioisotopes are usually eluted from a commercially available ${ }^{68} \mathrm{Ge} /{ }^{68} \mathrm{Ga}$ generator, Galabeled agents can be produced on-site at relatively low costs. Typically, the conjugation of ${ }^{68} \mathrm{Ga}$ bimodal probes requires 16-30 minutes ${ }^{34,42,50,54,56}$ and results in a good decay-corrected RY (80-97.4\%). ${ }^{71}$ Noteworthy, ${ }^{68} \mathrm{Ga}$ tends to form stable complexes with ligands originally meant for Gd, which may limit its application for labeling Gd-based MRI CAs. ${ }^{71}$

Although ${ }^{18} \mathrm{~F}$-based radioligands are widely used in clinical practice, ${ }^{91,92}$ there are not many reports on bimodal probes labeled with this isotope. In 2010, Frullano et al presented a bimodal imaging agent based on GdMRI CA radiolabeled with ${ }^{18} \mathrm{~F}^{40}$ The labeling reaction and purification process took $235 \mathrm{~min}$, which was over twice as long as the half-life of the isotope. Although the radiochemical purity was $>95 \%$, the product activity was only $10.2 \mathrm{kBq}$, which gave $0.006 \%$ of RY (starting activity: $1.8 \mathrm{GBq}$ ). On the other hand, Cui et al reported that SPIONs could be radiolabeled within 50 min with ${ }^{18} \mathrm{~F}$ and 20 min with ${ }^{64} \mathrm{Cu}$, with an RY of $70 \%$ and nearly $100 \%$, respectively. ${ }^{53}$ Also, several other groups have shown that the radiolabeling of bimodal agents with ${ }^{64} \mathrm{Cu}$ may take longer $(\sim 1 \mathrm{~h})$ but still provides the conjugates with a relatively high RY of $85-95 \%$. ${ }^{48,59}$

Chakravarty et al reported SPIONs labeled with ${ }^{69} \mathrm{Ge}^{52}$ The long radionuclide half-life allowed the labeling process to be extended to $24 \mathrm{~h}$, improving the RY from $75 \%$ (after 3 h) to $90 \%$ (after $24 \mathrm{~h}$; values not decay-corrected).

Recently, ${ }^{89} \mathrm{Zr}$ has gained interest for the labeling of bimodal probes, as its half-life is well suited for the conjugation of monoclonal antibodies. ${ }^{93}$ Even though the radiolabeling procedures take about $3 \mathrm{~h}$, the RYs are not greatly affected by nuclear disintegration. Gholami et $\mathrm{al}^{61}$ reported an RY of $\sim 92 \%$ (89\% after decay correction) for ${ }^{89} \mathrm{Zr}$-labeled SPIONs. The efficiency of labeling a lipid-based bimodal probe with $\left[{ }^{89} \mathrm{Zr}\right] \mathrm{Zr}$-hydroxide chloride was reported to be $99 \%$, only at very low concentrations of both substrates, and decreased exponentially when the lipid concentration increased. ${ }^{45}$

To evaluate whether a radioisotope's half-life influences the labeling yield, we compared the ratio of the time required to label a molecule to the isotope's halflife $(R)$ and reaction radiochemical yield (the percentage of activity remaining after the preparation of a probe) using several recent reports (Figure 5). It seems that the higher the $R$, the lower the activity after the labeling procedure due to radioactive decay of the radioisotope; however, a high $R$ does not necessarily mean a low RY value, as presented in Figure 5. Moreover, extending the labeling time (ie, a bigger R) may improve RY.

\section{Probes in Real-World Applications - In vivo Studies \\ Dose}

For gadolinium $T_{1}$ positive MRI CAs, the recommended dose is $0.1 \mathrm{mmol} / \mathrm{kg}^{26}$ which is a compromise between the expected visual contrast and patient safety; however, as it has been shown, this might be insufficient, especially in low magnetic fields. On the other hand, excessive concentrations (ie, $2 \mathrm{mmol} / \mathrm{kg}$ ), in addition to possible toxicity, might also lead to lower contrast images due to $T_{2}$ effects. Gholami et al showed oversaturation of the $T_{2}$ effects, where initially both $T_{1}$ and $T_{2}$ acceleration of the SPION bimodal CA increased when the Fe molarity concentration reached $0.5 \mathrm{mFe}$. Subsequently, $T_{1}$ but not $T_{2}$ rapidly dropped. ${ }^{61}$ These results show the limited applicability of this probe when used at higher doses. 


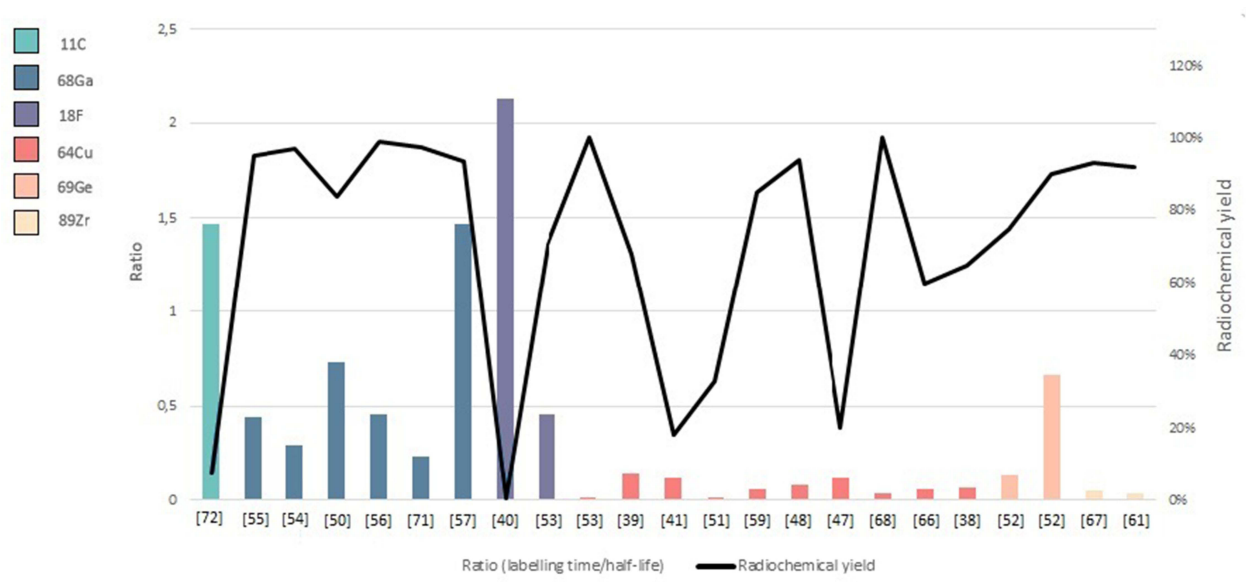

Figure 5 Ratios $(R)$ of labeling time/half-life and the radiochemical yields of some reported bimodal probes. $R$ was counted for probes with a known labeling time.

The sensitivity of MR scanners is still being improved, for example, a $4 \mathrm{~T}$ calibration spectrometer has been constructed; ${ }^{94}$ however, to decrease the doses of MRI contrast agents, the magnetic field strength should be increased. The recently introduced $3 \mathrm{~T}$ MRI scanners have already enhanced the value of this technique in medical diagnosis by improving the spatial resolution and sequence portfolios; however, further leaps in the strength of the magnetic field are not expected soon. One apparently simple solution for such a mésalliance in the dose of a bimodal probe is magnetic nanomaterials, which encompasses thousands or millions of superparamagnetic units with several atoms of nuclides.

The doses of applied radionuclides in PET imaging are in the nanomolar range, which is several orders lower than that of MRI CAs. ${ }^{13}$ To better design bimodal probes and adjust the amount of MRI CAs and radioisotopes, magnetic nanomaterials that contain thousands or millions of superparamagnetic units with several nuclide atoms can be introduced. This approach has already been described by using nanostructures where a magnetic core was covered by a much smaller amount of radioisotope. Chen et al ${ }^{95}$ reported a probe with a $\mathrm{Gd}:{ }^{64} \mathrm{Cu}$ molar ratio of 32 : $1,000,000$, which corresponded well with the difference in sensitivity.

\section{Distribution, Accumulation, Clearance}

The clearance of bimodal probes mostly depends on the size of the particles. Smaller molecules $(\leq 60 \mathrm{kDa})$ are removed faster by the renal system, and larger ones $(\geq$ $60 \mathrm{kDa}$ ) have longer circulation times and are removed via the hepatobiliary system. ${ }^{96}$ The conjugate should circulate in the system long enough to reach the region of interest while being rapidly cleared from normal tissues. Due to their rather large size, SPION-based bimodal probes circulate in the vascular system for at least several hours, heavily accumulating in the liver and spleen, whereas Gd complexes are quickly excreted via the kidneys. ${ }^{54,67}$

So far, the pharmacokinetics studies in the majority of cases were performed up to $48 \mathrm{~h}$. Mice were sacrificed, and their organ-associated radioactivity was measured via a gamma counter. ${ }^{23,57} \mathrm{~A}$ few studies have demonstrated longitudinal clearance (up to six days) of bimodal probes, which significantly limits our understanding of their behavior in vivo. ${ }^{37,46}$

A longitudinal study was performed by Chen et al, where mice were injected with a ${ }^{89} \mathrm{Zr}$-labeled gadofullerene-based probe and scanned at different times up to 720 h post-injection. ${ }^{95}$ PET scans showed that majority of radioactivity accumulated in the liver, confirming the hepatobiliary clearance of this nanostructure. The low bladder uptake at 0.5 and $3 \mathrm{~h}$ post-injection was most likely related to the renal excretion of some small parts of the spontaneously disassembled probe; thus, the slight renal clearance of the nanostructure was observed. Importantly, after only $20 \mathrm{~h}$ post-injection, the uptake in other organs was negligible. This could be proof that no free ${ }^{89} \mathrm{Zr}$ accumulated in the bones, but the deposition of high-energy gamma particles may put a heavy strain on organ of clearance. ${ }^{89} \mathrm{Zr}$-labeled probe remaining in the system for $720 \mathrm{~h}$ post-injection could potentially lead to severe systemic cytotoxicity. 


\section{Super Probes}

\section{Bioresponsive Characteristics, Theranostics}

Molecular machines and other "smart molecules," ie, species that change their physical properties upon the application of environmental stimuli, have also been developed for medical diagnoses. Thus, to build MRI-PET systems, probes were developed that had bioresponsive characteristics (Table 5). Caravan et al investigated a $\mathrm{pH}$-sensitive Gd(MRI)- ${ }^{18} \mathrm{~F}(\mathrm{PET})$ conjugate with phosphoric acid residues ${ }^{40}$ as these groups are responsible for reversible protonation. In vitro studies demonstrated a linear dependence of relaxivity $r_{1}$ and PET signal in the $\mathrm{pH}$ range 6-8. This $\mathrm{pH}$ range is of particular significance for the diagnosis of cancers, since tumor cells have a lower $\mathrm{pH}(<7)$ than healthy organs. Botta et al managed to selectively incorporate two metals Gd(MRI)- ${ }^{68} \mathrm{Ga}$ (PET) into two separated chelating systems linked to a $\mathrm{pH}$-sensitive fragment. ${ }^{42}$ Deprotonation of the sulfonamide nitrogen atom in the linker was responsible for an $r_{1}$ change in a similar $6-8 \mathrm{pH}$ range in the in vitro studies. A more elaborate structure was designed by Notni and coworkers, where a central ${ }^{68} \mathrm{Ga}(\mathrm{PET})$ chelate was surrounded by three Gd(MRI) arms. ${ }^{71}$ The relaxivity change was registered at $25{ }^{\circ} \mathrm{C}$ and $37{ }^{\circ} \mathrm{C}$, but only in vitro studies were provided of the bioresponsive functionality, whereas in vivo PET/MRI studies of rats were focused on classical contrast imaging. Finally, an NP "super probe" was obtained by Yang and coworkers. ${ }^{49}$ A SPION was functionalized with chelated ${ }^{64} \mathrm{Cu}$ radionuclides, PEG to enhance its dispersibility, cyclic arginine-glycine-aspartic acid

Table 5 Bioresponsive Characteristics of MRI/PET Probes

\begin{tabular}{|c|c|c|c|}
\hline Probe & $\begin{array}{l}\text { Stimulus, } \\
\text { Range }\end{array}$ & $\begin{array}{l}\text { Effect MRI } \\
\text { Relaxivity, PET } \\
\text { Signal }\end{array}$ & Ref \\
\hline $\begin{array}{l}\text { Furallo20I0- } \\
\text { GdDOTA-4AMP-F }\end{array}$ & $\mathrm{pH} 6-8$ & $\begin{array}{l}r_{1} 6-8 \mathrm{mmol}^{-1} \mathrm{~s}^{-1} \\
\text { in vitro }\end{array}$ & [40] \\
\hline $\begin{array}{l}\text { Vologdin20I3- } \\
\text { [GdDO3A-SAGa } \\
(\text { AAZTA)] }\end{array}$ & $\mathrm{pH} 6 \mathrm{v} 8$ & $\begin{array}{l}r_{1} 4-10 \mathrm{mmol}^{-1} \mathrm{~s}^{-1} \\
\text { in vitro }\end{array}$ & [42] \\
\hline $\begin{array}{l}\text { Notni20I3- TRAP } \\
\text { (HMDA-DOTA)3 }\end{array}$ & $\begin{array}{l}\text { Temp. 25/ } \\
37^{\circ} \mathrm{C}\end{array}$ & $\begin{array}{l}r_{1} 5.69 / 4.73(7 \mathrm{~T}) \text { or } \\
7.06 / 5.69 \mathrm{mmol}^{-1} \mathrm{~s}^{-1} \\
(0.5 \mathrm{~T})\end{array}$ & [7I] \\
\hline Yang20II & $\mathrm{pH} 5.3 / 7.4$ & $\begin{array}{l}\text { Drug (doxorubicin) } \\
\text { release }\end{array}$ & [49] \\
\hline
\end{tabular}

(cRGD) peptide targeting integrin $\alpha v \beta 3$, and drugreleasing centers. In vitro studies showed rapid drug release within $35 \mathrm{~min}$ at $\mathrm{pH}=5.3$, but there was no release at $\mathrm{pH}=7.4$. MMT assays showed an improved ability to penetrate both cell and nuclear membranes due to the presence of the drug-release moieties. The in vivo biodistribution studies using mouse models showed the accumulation of the bimodal probe in tumors, liver, and kidneys.

Generally, bioresponsive contrast agents and molecular probes are the main methods to enhance species for imaging techniques. ${ }^{99,100}$ This enthusiasm has been driven by visions of using particles to detect abnormalities internally and visualized by scanners and tomographs; however, the last 15 years of investigations in responsive MRI contrast agents have led to a more inquisitive and critical assessment of these probes. Some problems have been found in early research in Meade's group, where competitive interactions with carbonates were found in biofluids, which hampered the detection of MRI signal changes in some stereoisomers. ${ }^{101}$ However, an insightful but critical attitude with clear calculations and transfer of the in vitro data to in vivo systems was presented by Pagel and coworkers. ${ }^{102}$ The authors paid attention to the low sensitivity of MRI in examinations with respect to the magnitude of the physical changes of the responsive probes described in the literature. Their concentration (below several micromoles) in tissue with a $20 \%$ change in their properties could not be detected by current scanners. According to the authors' view, increasing the field will not help, since the relaxivities dropped even in a stronger magnetic field. While this is generally consistent with relaxation theory, ${ }^{21}$ our studies have shown that nongadolinium contrast agents are efficient in fields up to 7 T. ${ }^{103}$ Another more optimistic scenario is focusing on PET's high sensitivity and designing bioresponsive characteristics mainly for this modality.

\section{Summary and Outlook}

The application of imaging techniques (MRI and PET) over the last 20 years has given a much better understanding of the biological, chemical, and physical processes occurring in the human body. Importantly, both modalities provide the means to identify early diseases, differentiate benign from malignant lesions, and determine the therapeutic effectiveness of many therapeutic regimens.

Herein, we have summarized the most recent reports focusing on the development of bimodal imaging probes being used for PET/MRI. Most of these agents are far 
Table 6 Main Features of Classic Complexes and Nanoparticles as Potential MRI-PET Bimodal Probes

\begin{tabular}{|l|l|l|}
\hline & Discrete Complexes & Nanoparticles \\
\hline $\begin{array}{l}\text { Visual } \\
\text { effect in } \\
\text { MRI }\end{array}$ & Brightening, no general drawbacks & $\begin{array}{l}\text { Darkening, may hamper discrimination from bulk, } \\
\text { artifacts overlap, first reports as } T_{1} / T_{2} \text { dual } C A s\end{array}$ \\
\hline Preparation & Rapid, selective & Might be even more rapid, often chelator free \\
\hline Size & $<\mathrm{I} \mathrm{nm}$ & $20-140 \mathrm{~nm}$ \\
\hline Clearance & Kidney (as long as $r<5.5 \mathrm{~nm})$ & $\begin{array}{l}\text { Absorbed by the reticuloendothelial system in the } \\
\text { liver and spleen }\end{array}$ \\
\hline Targeting & Intercellular and intracellular & Intercellular, vascular system \\
\hline Advantages & $\begin{array}{l}\text { Large experience based on hitherto applications }- \text { known pharmacokinetics, } \\
\text { clearance, possible bioresponsive characteristics, higher flexibility in targeting }\end{array}$ & $\begin{array}{l}\text { Great potential in parallel drug delivery and } \\
\text { theranostic functions }\end{array}$ \\
\hline Drawbacks & $\begin{array}{l}\text { Limited control over the paramagnet/radionuclide ratio desired for good } \\
\text { performance of both modalities; Radiolabelling might be not selective }\end{array}$ & $\begin{array}{l}\text { Limited permeability due to size } \\
\text { Fears of deposition } \\
\text { Poor MRI contrast } \\
\text { Potentially lower bioresponsive characteristics }\end{array}$ \\
\hline
\end{tabular}

from optimal for clinical applications; however, if mutual efforts from biologists, medicinal chemists/radiochemists, and engineers/medical physicists can be directed towards improving the characterization of these probes, they might be used in the future in the image-guided delivery of therapeutic agents. When designing these probes, there are still many factors that need to be optimized, including their biocompatibility, pharmacokinetics, targeting efficacy, acute and chronic toxicity, as well as costeffectiveness (Table 6).

Designing bimodal probes raises completely new issues that need to be addressed, such as the cytotoxicity of these complex molecules, the ratio of radionuclide to paramagnetic agent, and the clearance of complex molecules. Clinical trials of the proposed probes are still lacking, but there is growing interest in multimodal imaging, which is confirmed by the increasing number of publications on this topic. Although the application of PET radiotracers is necessary, the development of numerical methods and quantum computers might diminish the need for MRI CAs applications; however, the detection of hepatic or stroke-originated lesions, as well as biomarker sensing, molecular imaging, and theranostics should be further investigated in the field of MRI enhancement. ${ }^{104}$ Additionally, as specialists have emphasized, future developments should focus on features such as targeting and high efficiencies with low doses and multimodal characteristics. ${ }^{99,100}$ Such efforts should hopefully give us an "all-in-one" specific pill.

\section{Acknowledgments}

This publication was supported (KB) by The Excellence Initiative - Research University Program realized at the Silesian University of Technology, Grant No. 04/020/ SDU/10-22-02, year 2020. This review (PJ) was supported by the Czech Science Foundation (GAČR) under the EXPRO 21-20716X project.

\section{Disclosure}

The authors report no conflicts of interest in this work.

\section{References}

1. Leeflang MMG, Allerberger F. How to: evaluate a diagnostic test. Clin Microbiol Infect. 2019;25(1):54-59. doi:10.1016/j.cmi.2018.06.011

2. Chen Z-Y, Wang Y-X, Lin Y, et al. Advance of molecular imaging technology and targeted imaging agent in imaging and therapy. Biomed Res Int. 2014;2014:1-12. doi:10.1155/2014/819324

3. Picano E. Sustainability of medical imaging. Br Med J. 2004;328 (7439):578-580. doi:10.1136/bmj.328.7439.578

4. Stucht D, Danishad KA, Schulze P, Godenschweger F, Zaitsev M, Speck O. Highest resolution in vivo human brain MRI using prospective motion correction. PLoS One. 2015;10(7):1-17. doi:10.1371/journal.pone.0133921

5. Kramer-Marek G, Capala J. Can PET imaging facilitate optimization of cancer therapies? Curr Pharm Des. 2012;18(18):2657-2669. doi: $10.2174 / 138161212800492813$

6. Davidson CL, Heldebrant DJ, Bearden MD, Horner JA, Freeman CJ. The IUPAC Compendium of Chemical Terminology. Vol. 114. Gold V ed. Research Triangle Park, NC: International Union of Pure and Applied Chemistry (IUPAC); 2019. doi:10.1351/goldbook

7. Weishaupt D, Köchli VD, Marincek B. How Does MRI Work? Berlin, Heidelberg: Springer Berlin Heidelberg; 2006. doi:10.1007/978-3-54037845-7 
8. Westbrook C, Talbot J. MRI in Practice. 5th ed. John Wiley \& Sons Inc; 2018.

9. Dryzek J. Charakterystyki procesu anihilacji pozytonów w materii. 2000. doi:10.4103/0971-6203.25665

10. Wadsak W, Mitterhauser M. Basics and principles of radiopharmaceuticals for PET/CT. Eur J Radiol. 2010;73(3):461-469. doi:10.1016/j.ejrad.2009.12.022

11. Treglia G, Salsano M. PET imaging using radiolabelled antibodies: future direction in tumor diagnosis and correlate applications. Res Rep Nucl Med. 2013;9. doi:10.2147/rrnm.s35186

12. Yang CT, Ghosh KK, Padmanabhan P, et al. PET-MR and SPECT-MR multimodality probes: development and challenges. Theranostics. 2018;8(22):6210-6232. doi:10.7150/thno.26610

13. Lamb J, Holland JP. Advanced methods for radiolabeling multimodality nanomedicines for SPECT/MRI and PET/MRI. $J$ Nucl Med. 2018;59(3):382-389. doi:10.2967/jnumed.116.187419

14. Dammes N, Peer D. Monoclonal antibody-based molecular imaging strategies and theranostic opportunities. Theranostics. 2020;10(2):938-955. doi:10.7150/thno.37443

15. Bulte JWM, Kraitchman DL. Iron oxide MR contrast agents for molecular and cellular imaging. NMR Biomed. 2004;17 (7):484-499. doi:10.1002/nbm.924

16. Estelrich J, Sánchez-Martín MJ, Busquets MA. Nanoparticles in magnetic resonance imaging: from simple to dual contrast agents. Int J Nanomed. 2015;10:1727-1741. doi:10.2147/IJN.S76501

17. Na HB, Song IC, Hyeon T. Inorganic nanoparticles for MRI contrast agents. Adv Mater. 2009;21(21):2133-2148. doi:10.1002/adma.200802366

18. Wood ML, Hardy PA. Proton relaxation enhancement. J Magn Reson Imaging. 1993;3(1):149-156. doi:10.1002/jmri.18800 30127

19. Bloembergen N. Proton relaxation times in paramagnetic solutions. J Chem Phys. 1957;27(2):572-573. doi:10.1063/ 1.1743771

20. Strandberg E, Westlund PO. 1H NMRD profile and ESR lineshape calculation for an isotropic electron spin system with $\mathrm{S}=7$ / 2. A generalized modified solomon-bloembergen-morgan theory for nonextreme-narrowing conditions. J Magn Reson. 1996;122 (2):179-191. doi:10.1006/jmra.1996.0193

21. Lauffer RB. Paramagnetic metal complexes as water proton relaxation agents for NMR imaging: theory and design. Chem Rev. 1987;87(5):901-927. doi:10.1021/cr00081a003

22. Terencio T, Roithová J, Brandès S, Rousselin Y, Penouilh MJ, Meyer M. A comparative IRMPD and DFT study of $\mathrm{Fe} 3+$ and $\mathrm{UO} 22+$ complexation with N-methylacetohydroxamic acid. Inorg Chem. 2018;57(3):1125-1135. doi:10.1021/acs.inorgchem.7b 02567

23. Aryal S, Key J, Stigliano C, Landis MD, Lee DY, Decuzzi P. Positron emitting magnetic nanoconstructs for PET/MR imaging. Small. 2014;10(13):2688-2696. doi:10.1002/smll.201303933

24. Verwilst P, Park S, Yoon B, Kim JS. Recent advances in Gd-chelate based bimodal optical/MRI contrast agents. Chem Soc Rev. 2015;44(7):1791-1806. doi:10.1039/c4cs00336e

25. Caravan P, Ellison JJ, McMurry TJ, Lauffer RB. Gadolinium(III) chelates as MRI contrast agents: structure, dynamics, and applications. Chem Rev. 1999;99(9):2293-2352. doi:10.1021/ cr980440x

26. Rinck PA, Muller RN. Field strength and dose dependence of contrast enhancement by gadolinium-based MR contrast agents. Eur Radiol. 1999;9(5):998-1004. doi:10.1007/s003300050781

27. Kellar KE, Fujii DK, Gunther WHH, Briley-Sæbø K, Spiller M, Koenig SH. 'NC100150', a preparation of iron oxide nanoparticles ideal for positive-contrast MR angiography. Magma Magn Reson Mater Phys Biol Med. 1999;8(3):207-213. doi:10.1007/ BF02594600
28. Taboada E, Rodríguez E, Roig A, Oró J, Roch A, Muller RN Relaxometric and magnetic characterization of ultrasmall iron oxide nanoparticles with high magnetization. Evaluation as potential T1 magnetic resonance imaging contrast agents for molecular imaging. Langmuir. 2007;23(8):4583-4588. doi:10.1021/ la063415s

29. Das S, Parga K, Chakraborty I, et al. Magnetic resonance imaging contrast enhancement in vitro and in vivo by octanuclear iron-oxo cluster-based agents. J Inorg Biochem. 2018;186:176-186. doi:10.1016/j.jinorgbio.2018.06.005

30. Marangon I, Ménard-Moyon C, Kolosnjaj-Tabi J, et al. Covalent functionalization of multi-walled carbon nanotubes with a gadolinium chelate for efficient T1-weighted magnetic resonance imaging. Adv Funct Mater. 2014;24(45):7173-7186. doi:10.1002/adfm.201402234

31. Ananta JS, Matson ML, Tang AM, et al. Single-walled carbon nanotube materials as T2-weighted MRI contrast agents. $J$ Phys Chem C. 2009;113(45):19369-19372. doi:10.1021/jp907891n

32. Engelking LR. Chapter 4 - protein structure. Textb Vet Physiol Chem. 2015;18-25. doi:10.1016/B978-0-12-391909-0.50004-9

33. Turgeon ML. Clinical Hematology: Theory and Procedures. 4th ed. Kraków: Lippincott Williams \& Wilkins; 2004.

34. Kim S, Chae MK, Yim MS, et al. Hybrid PET/MR imaging of tumors using an oleanolic acid-conjugated nanoparticle. Biomaterials. 2013;34(33):8114-8121. doi:10.1016/j. biomaterials.2013.07.078

35. Chen F, Ellison PA, Lewis CM, et al. Chelator-free synthesis of a dual-modality PET/MRI agent. Angew Chem Int Ed Engl. 2013;23(1):1-7. doi:10.1002/anie.201306306.Chelator-Free

36. Lee HY, Li Z, Chen K, et al. PET/MRI dual-modality tumor imaging using arginine-glycine-aspartic (RGD)-conjugated radiolabeled iron oxide nanoparticles. $J$ Nucl Med. 2008;49 (8):1371-1379. doi:10.2967/jnumed.108.051243

37. Choi JS, Park JC, Nah H, et al. A hybrid nanoparticle probe for dual-modality positron emission tomography and magnetic resonance imaging. Angew Chemie. 2008;47(33):6259-6262. doi:10.1002/anie.200801369

38. Shi $X$, Shen L. Integrin $\alpha \vee \beta 3$ receptor targeting PET/MRI dualmodal imaging probe based on the $64 \mathrm{Cu}$ labeled manganese ferrite nanoparticles. J Inorg Biochem. 2018;186:257-263. doi:10.1016/j.jinorgbio.2018.06.004

39. Tu C, Ng TSC, Jacobs RE, Louie AY. Multimodality PET/MRI agents targeted to activated macrophages topical issue on metal-based MRI contrast agents. Guest editor: Valerie C. Pierre. J Biol Inorg Chem. 2014;19(2):247-258. doi:10.1007/ s00775-013-1054-9

40. Frullano L, Catana C, Benner T, Sherry AD, Caravan P. Bimodal MR-PET agent for quantitative $\mathrm{pH}$ imaging. Angew Chemie. 2010;49(13):2382-2384. doi:10.1002/anie.201000075

41. Uppal R, Catana C, Ay I, Benner T, Sorensen AG, Caravan P. Bimodal thrombus imaging: simultaneous PET/MR imaging with a fibrin-targeted dual PET/MR probe-feasibility study in rat model. Radiology. 2011;258(3):812-820. doi:10.1148/radiol.1 0100881

42. Vologdin N, Rolla GA, Botta M, Tei L. Orthogonal synthesis of a heterodimeric ligand for the development of the GdIII-GaIII ditopic complex as a potential $\mathrm{pH}$-sensitive MRI/PET probe. Org Biomol Chem. 2013;11(10):1683-1690. doi:10.1039/c2ob27200h

43. Devreux M, Henoumont C, Dioury F, et al. Bimodal probe for magnetic resonance imaging and photoacoustic imaging based on a PCTA-derived gadolinium(III) complex and ZW800-1. Eur J Inorg Chem. 2019;2019(29):3354-3365. doi:10.1002/ ejic.201900387

44. Wang Y-XJ. Superparamagnetic iron oxide based MRI contrast agents: current status of clinical application. Quant Imaging Med Surg. 2011;1(1):35-40. doi:10.3978/j.issn.2223-4292.2011.08.03 
45. Thorek DLJ, Ulmert D, Diop N-FM, et al. Non-invasive mapping of deep-tissue lymph nodes in live animals using a multimodal PET/MRI nanoparticle. Nat Commun. 2014;5(1):3097. doi:10.1038/ncomms4097

46. Knobloch G, Colgan T, Wiens CN, et al. Relaxivity of ferumoxytol at $1.5 \mathrm{~T}$ and $3.0 \mathrm{~T}$. Invest Radiol. 2018;53(5):257-263. doi:10.1097/RLI.0000000000000434

47. Jarrett BR, Gustafsson B, Kukis DL, Louie AY. Synthesis of 64 $\mathrm{Cu}$-labeled magnetic nanoparticles for multimodal imaging. Bioconjug Chem. 2008;19(7):1496-1504. doi:10.1021/bc800108v. Synthesis

48. Glaus C, Rossin R, Welch MJ, Bao G. In vivo evaluation of 64Cu-labeled magnetic nanoparticles as a dual-modality PET/ MR imaging agent. Bioconjug Chem. 2010;21(4):715-722. doi:10.1021/bc900511j

49. Yang $X$, Hong $H$, Grailer JJ, et al. cRGD-functionalized, DOX-conjugated, and $64 \mathrm{Cu}$-labeled superparamagnetic iron oxide nanoparticles for targeted anticancer drug delivery and PET/MR imaging. Biomaterials. 2011;32(17):4151. doi:10.1016/ j.biomaterials.2011.02.006.cRGD-functionalized

50. Locatelli E, Gil L, Israel LL, et al. Biocompatible nanocomposite for PET/MRI hybrid imaging. Int $J$ Nanomedicine. 2012;7:6021-6033. doi:10.2147/IJN.S38107

51. Wong RM, Gilbert DA, Liu K, Louie AY. Rapid size-controlled synthesis of oxide nanoparticles. ACS Nano. 2012;6 (4):3461-3467. doi:10.1021/nn300494k

52. Chakravarty R, Valdovinos HF, Chen $\mathrm{F}$, et al. Intrinsically germanium-69 labeled iron oxide nanoparticle: synthesis and in vivo dual-modality PET/MR imaging. Physiol Behav. 2014;176(1):100-106. doi:10.1002/adma.201401372.

53. Cui X, Belo S, Krüger D, et al. Aluminium hydroxide stabilised $\mathrm{MnFe} 2 \mathrm{O} 4$ and $\mathrm{Fe} 3 \mathrm{O} 4$ nanoparticles as dual-modality contrasts agent for MRI and PET imaging. Biomaterials. 2014;35 (22):5840-5846. doi:10.1016/j.biomaterials.2014.04.004

54. Truillet C, Bouziotis P, Tsoukalas C, et al. Ultrasmall particles for Gd-MRI and 68Ga-PET dual imaging. Contrast Media Mol Imaging. 2015;10(4):309-319. doi:10.1002/cmmi.1633

55. Yang BY, Moon SH, Seelam SR, et al. Development of a multimodal imaging probe by encapsulating iron oxide nanoparticles with functionalized amphiphiles for lymph node imaging. Nanomedicine. 2015;10(12):1899-1910. doi:10.2217/ nnm. 15.41

56. Moon SH, Yang BY, Kim YJ, et al. Development of a complementary PET/MR dual-modal imaging probe for targeting prostate-specific membrane antigen (PSMA). Nanomed Nanotechnol Biol Med. 2016;12(4):871-879. doi:10.1016/j.nano.2015.12.368

57. Pellico J, Ruiz-Cabello J, Saiz-Alía M, et al. Fast synthesis and bioconjugation of $68 \mathrm{Ga}$ core-doped extremely small iron oxide nanoparticles for PET/MR imaging. Contrast Media Mol Imaging. 2016;11(3):203-210. doi:10.1002/cmmi.1681

58. Nguyen Pham TH, Lengkeek NA, Greguric I, et al. Tunable and noncytotoxic PET/SPECT-MRI multimodality imaging probes using colloidally stable ligand-free superparamagnetic iron oxide nanoparticles. Int J Nanomed. 2017;12:899-909. doi:10.2147/ IJN.S127171

59. Zhu J, Li H, Xiong Z, et al. Polyethyleneimine-coated manganese oxide nanoparticles for targeted tumor PET/MR imaging. ACS Appl Mater Interfaces. 2018;10(41):34954-34964. doi:10.1021/ acsami.8b12355

60. Thakare V, Tran VL, Natuzzi M, et al. Functionalization of theranostic AGuIX ${ }^{\circledR}$ nanoparticles for PET/MRI/optical imaging. RSC Adv. 2019;9(43):24811-24815. doi:10.1039/c9ra00365g

61. Gholami YH, Yuan H, Wilks MQ, et al. A radio-nano-platform for T1/T2 dual-mode PET-MR imaging. Int $J$ Nanomed. 2020;15:1253-1266. doi:10.2147/IJN.S241971
62. Xu F, Li X, Chen H, et al. Synthesis of heteronanostructures for multimodality molecular imaging-guided photothermal therapy. J Mater Chem B. 2020;8(44):10136-10145. doi:10.1039/ d0tb02136a

63. Shaw TB, Jeffree RL, Thomas P, et al. Diagnostic performance of $18 \mathrm{~F}$-fluorodeoxyglucose positron emission tomography in the evaluation of glioma. J Med Imaging Radiat Oncol. 2019;63 (5):650-656. doi:10.1111/1754-9485.12929

64. Groult H, Ruiz-Cabello J, Pellico J, et al. Parallel multifunctionalization of nanoparticles: a one-step modular approach for in vivo imaging. Bioconjug Chem. 2015;26(1):153-160. doi:10.1021/bc500536y

65. Yang M, Fan Q, Zhang R, et al. Dragon fruit-like biocage as an iron trapping nanoplatform for high efficiency targeted cancer multimodality imaging. Biomaterials. 2015;69:30-37. doi:10.1016/j.biomaterials.2015.08.001

66. Thomas G, Boudon J, Maurizi L, et al. Innovative magnetic nanoparticles for PET/MRI bimodal imaging. ACS Omega. 2019;4(2):2637-2648. doi:10.1021/acsomega.8b03283

67. Boros E, Bowen AM, Josephson L, Vasdev N, Holland JP. Chelate-free metal ion binding and heat-induced radiolabeling of iron oxide nanoparticles. Chem Sci. 2015;6(1):225-236. doi:10.1039/c4sc02778g

68. Torres Martin de Rosales R, Tavaré R, Paul RL, et al. Synthesis of $64 \mathrm{Cu}$ II -Bis(dithiocarbamatebisphosphonate) and its conjugation with superparamagnetic iron oxide nanoparticles: in vivo evaluation as dual-modality PET-MRI agent. Angew Chemie. 2011;50 (24):5509-5513. doi:10.1002/anie.201007894

69. Abou DS, Thorek DLJ, Ramos NN, et al. 89Zr-labeled paramagnetic octreotide-liposomes for PET-MR imaging of cancer. Pharm Res. 2013;30(3):878-888. doi:10.1007/s11095-012-0929-8

70. Desbois N, Michelin C, Chang Y, et al. Synthetic strategy for preparation of a folate corrole DOTA heterobimetallic $\mathrm{Cu}-\mathrm{Gd}$ complex as a potential bimodal contrast agent in medical imaging. Tetrahedron Lett. 2015;56(51):7128-7131. doi:10.1016/j.tetlet.2015.11.032

71. Notni J, Hermann P, Dregely I, Wester HJ. Convenient synthesis of 68Ga-labeled gadolinium(III) complexes: towards bimodal responsive probes for functional imaging with PET/MRI. Chem a Eur J. 2013;19(38):12602-12606. doi:10.1002/chem.201302751

72. Sharma R, Xu Y, Kim SW, et al. Carbon-11 radiolabeling of iron-oxide nanoparticles for dual-modality PET/MR imaging. Nanoscale. 2013;5(16):7476-7483. doi:10.1039/c3nr02519e

73. Naqvi S, Samim M, Abdin MZ, et al. Concentration-dependent toxicity of iron oxide nanoparticles mediated by increased oxidative stress. Int J Nanomed. 2010;5(1):983-989. doi:10.2147/IJN. S13244

74. Naghavi N, Ghoddusi J, Sadeghnia HR, Asadpour E, Asgary S. Genotoxicity and cytotoxicity of mineral trioxide aggregate and calcium enriched mixture cements on L929 mouse fibroblast cells. Dent Mater J. 2014;33(1):64-69. doi:10.4012/dmj.2013123

75. Abakumov MA, Semkina AS, Skorikov AS, et al. Toxicity of iron oxide nanoparticles: size and coating effects. J Biochem Mol Toxicol. 2018;32(12):1-6. doi:10.1002/jbt.22225

76. Wang Y, Alkasab TK, Narin O, et al. Incidence of nephrogenic systemic fibrosis after adoption of restrictive gadolinium-based contrast agent guidelines. Radiology. 2011;260(1):105-111. doi:10.1148/radiol.11102340

77. Kanda T, Ishii K, Kawaguchi H, Kitajima K, Takenaka D. High signal intensity in the dentate nucleus and globus pallidus on unenhanced T1-weighted MR images: relationship with increasing cumulative dose of a gadoliniumbased contrast material. Radiology. 2014;270(3):834-841. doi:10.1148/ radiol.13131669 
78. Rogosnitzky M, Branch S. Gadolinium-based contrast agent toxicity: a review of known and proposed mechanisms. BioMetals. 2016;29(3):365-376. doi:10.1007/s10534-016-9931-7

79. Harvey HB, Gowda V, Cheng G. Gadolinium deposition disease: a new risk management threat. J Am Coll Radiol. 2020;17 (4):546-550. doi:10.1016/j.jacr.2019.11.009

80. Radbruch A, Haase R, Kieslich PJ, et al. No signal intensity increase in the dentate nucleus on unenhanced T1-weighted MR images after more than 20 serial injections of macrocyclic gadolinium-based contrast agents. Radiology. 2017;282 (3):699-707. doi:10.1148/radiol.2016162241

81. Banerjee SR, Pomper MG. Clinical applications of Gallium-68. Appl Radiat Isot. 2013;76:2-13. doi:10.1016/j.apradiso.2013.01.039

82. Baum R, Rösch F. 1 st World Congress on Ga-68 and Peptide Receptor Radionuclide Therapy (PRRNT), June 23-26, 2011, Zentralklinik Bad Berka, Germany. World J Nucl Med. 2011;10 (1):5. doi:10.4103/1450-1147.82105

83. Fani M, André JP, Maecke HR. 68Ga-PET: a powerful generator-based alternative to cyclotron-based PET radiopharmaceuticals. Contrast Media Mol Imaging. 2008;3 (2):53-63. doi: $10.1002 / \mathrm{cmmi} .232$

84. Roesch F, Riss P. The renaissance of the $68 \mathrm{Ge} / 68 \mathrm{Ga}$ radionuclide generator initiates new developments in $68 \mathrm{Ga}$ radiopharmaceutical chemistry. Curr Top Med Chem. 2012;10(16):1633-1668. doi:10.2174/156802610793176738

85. Wadas TJ, Wong EH, Weisman GR, Anderson CJ. Coordinating radiometals of copper, gallium, indium, yttrium, and zirconium for PET and SPECT imaging of disease. Chem Rev. 2010;110 (5):2858-2902. doi:10.1021/cr900325h

86. Rösch F, Baum RP. Generator-based PET radiopharmaceuticals for molecular imaging of tumours: on the way to THERANOSTICS. Dalt Trans. 2011;40(23):6104. doi:10.1039/ c0dt01504k

87. Szydlo M, Pogoda D, Kowalski T, Pociegiel M, Jadwinski M, Amico AD. Synthesis and quality control of 68Ga-PSMA PET/ $\mathrm{CT}$ tracer used in prostate cancer imaging and comparison with 18F-fluorocholine as a reference point. J Pharm Sci Emerg Drugs. 2018;06(01). doi:10.4172/2380-9477.1000126

88. Pauwels E, Cleeren F, Bormans G, Deroose CM. Somatostatin receptor PET ligands - The next generation for clinical practice. Am J Nucl Mol Imaging. 2018;8(5):311-331.

89. Schuhmacher J, Zhang H, Doll J, et al. GRP receptor-targeted PET of a rat pancreas carcinoma xenograft in nude mice with a 68Ga-labeled bombesin (6-14) analog. J Nucl Med. 2005;46 (4):691-699.

90. Froidevaux S, Calame-christe M, Schuhmacher J, et al. A gallium-labeled DOTA- $\alpha$-melanocyte- stimulating hormone analog for PET imaging of melanoma metastases. $J$ Nucl Med. 2004;45(1):116-123.

91. Fletcher JW, Djulbegovic B, Soares HP, et al. Recommendations on the use of 18F-FDG PET in oncology. J Nucl Med. 2008;49 (3):480-508. doi:10.2967/jnumed.107.047787
92. Timmers HJ, Chen CC, Carrasquillo JA, et al. Comparison of 18F-fluoro-L-DOPA, 18F-fluoro- deoxyglucose, and18F-fluorodopamine PET and 123I-MIBG scintigraphy in the localization of pheochromocytoma and paraganglioma. J Clin Endocrinol Metab. 2009;94(12):4757-4767. doi:10.1210/ jc. $2009-1248$

93. Dias GM, Ramogida CF, Rousseau J, et al. 89Zr for antibody labeling and in vivo studies - a comparison between liquid and solid target production. Nucl Med Biol. 2018;58:1-7. doi:10.1016/ j.nucmedbio.2017.11.005

94. Farooq M, Chupp T, Grange J, et al. Absolute magnetometry with He 3. Phys Rev Lett. 2020;124(22):223001. doi:10.1103/ PhysRevLett.124.223001

95. Chen D, Zhou Y, Yang D, et al. Positron emission tomography/ magnetic resonance imaging of glioblastoma using a functionalized gadofullerene nanoparticle. ACS Appl Mater Interfaces. 2019;11(24):21343-21352. doi:10.1021/ acsami.9b03542

96. Bourquin J, Milosevic A, Hauser D, et al. Biodistribution, clearance, and long-term fate of clinically relevant nanomaterials. $A d v$ Mater. 2018;30(19):1704307. doi:10.1002/adma.201704307

97. Jarrett BR, Correa C, Ma KL, Louie AY. In vivo mapping of vascular inflammation using multimodal imaging. PLoS One. 2010;5(10):2-9. doi:10.1371/journal.pone.0013254

98. Uppal R, Ciesienski KL, Chonde DB, Loving GS, Caravan P. Discrete bimodal probes for thrombus imaging. J Am Chem Soc. 2012;134(26):10799-10802. doi:10.1021/ja3045635

99. Pierre VC, Allen MJ, Caravan P. Contrast agents for MRI: 30+ years and where are we going? Topical issue on metal-based MRI contrast agents. Guest editor: Valérie C. Pierre. J Biol Inorg Chem. 2014;19(2):127-131. doi:10.1007/s00775-013-1074-5

100. Morrow JR, Tóth É. Next-generation magnetic resonance imaging contrast agents. Inorg Chem. 2017;56(11):6029-6034. doi:10.1021/acs.inorgchem. $7 \mathrm{~b} 01277$

101. Duimstra JA, Femia FJ, Meade TJ. A gadolinium chelate for detection of $\beta$-glucuronidase: a self-immolative approach. $J \mathrm{Am}$ Chem Soc. 2005;127(37):12847-12855. doi:10.1021/ja042162r

102. Hingorani DV, Bernstein AS, Pagel MD. A review of responsive MRI contrast agents: 2005-2014. Contrast Media Mol Imaging. 2015;10(4):245-265. doi:10.1002/cmmi.1629

103. Kuźnik N, Wyskocka M. Iron(III) contrast agent candidates for MRI: a survey of the structure-effect relationship in the last 15 years of studies. Eur J Inorg Chem. 2016;2016(4):445-458. doi:10.1002/ejic.201501166

104. Wahsner J, Gale EM, Rodríguez-Rodríguez A, Caravan P. Chemistry of MRI contrast agents: current challenges and new frontiers. Chem Rev. 2019;119(2):957-1057. doi:10.1021/acs. chemrev.8b00363
International Journal of Nanomedicine

\section{Publish your work in this journal}

The International Journal of Nanomedicine is an international, peerreviewed journal focusing on the application of nanotechnology in diagnostics, therapeutics, and drug delivery systems throughout the biomedical field. This journal is indexed on PubMed Central, MedLine, CAS, SciSearch ${ }^{\mathbb{R}}$, Current Contents ${ }^{\mathbb{B}} /$ Clinical Medicine,
Journal Citation Reports/Science Edition, EMBase, Scopus and the Elsevier Bibliographic databases. The manuscript management system is completely online and includes a very quick and fair peer-review system, which is all easy to use. Visit http://www.dovepress.com/ testimonials.php to read real quotes from published authors. 